\title{
Boris Yeltsin'in Başkanlığı Döneminde Bilim, Yükseköğrenim ve Rusya Bilimler Akademisi Şarkiyat Enstitüsü Türkiye Birimi, 1992-2000
}

\section{Science, Higher Education and Turkey Unit of the Institute of Oriental Studies Russian Academy of Sciences during the Presidency of Boris Yeltsin, 1992-2000}

\author{
Ali Başaran ${ }^{1}$
}

'Sorumlu yazar/Corresponding author: Ali Başaran (Dr. Öğretim Üyesi), Karabük Üniversitesi, İșletme Fakültesi, Uluslararası Ticaret Bölümü, Karabük, Türkiye E-posta: alibasaran3@gmail.com ORCID: 0000-0002-1870-2495

Başvuru/Submitted: 08.08 .2020 Revizyon Talebi/Revision Requested: 08.09.2020

Son Revizyon/Last Revision Received: 10.09.2020

Kabul/Accepted: 22.09 .2020

Atıf/Citation: Basaran, Ali. "Boris Yeltsin'in Başkanlığı Döneminde Bilim, Yükseköğrenim ve Rusya Bilimler Akademisi Şarkiyat Enstitüsü Türkiye Birimi, 1992-2000.", Avrasya Incelemeleri Dergisi - Journal of Eurasian Inquiries 9, 2 (2020): 141-170.

https://doi.org/10.26650/jes.2020.011

\section{ÖZ}

Araştırmanın amacı SSCB sonrası Rusya Federasyonu'nda bilim, araştırma kurumlarının ve araştırmacıların durumunu tespit etmektir. Resmî kurumların raporları, Federal Devlet İstatistik Hizmetleri istatistikleri, akademisyenlerin beyanatları, Şarkiyat Enstitüsünün yayınları, Bilim Tetkikleri Enstitüsü yayınları, Şarkiyat Enstitüsünün 200'ncü kuruluş yıldönümü için hazırladığı belgesel, Rusya Devlet Kütüphanesine kayıtlı Türkiye hakkındaki tezler kullanılmıştır. SSCB'de ve Yeltsin döneminde bilim, araştırma kurumlarının ve araştırmacıların durumunu tespit edildikten sonra Türkiye biriminin Şarkiyat Enstitüsü içindeki yeri ve rolü, personel yapısı, yayınları, yayınlarının niteliği, yayınlarının sayısı belirlenmiştir. Türkiye biriminin araştırmalarına RF yönetiminin tesiri değerlendirilmiştir. Sovyetler Birliğinde ve RF'de araştırmacılar özgür, araştırmalar olağan akışına bırakılmamıştır. Türkiye biriminin yapısı ve araştırmaları yönlendirilmiş̧ir. Araştırma kurumları ve araştırmacılar Yeltsin dönemi öncesi ve sonrası ile karşılaştırılmıştır. Araştırma kurumlarında çalışanların sayısı yaklaşık yarıya düşmüştür. Düşüşün en önemli nedenleri arasında maaşların ödenmemesi, maaşların SSCB dönemine nispeten çok düşmesi, araştırmacılara imkân ve değer verilmemesi, araştırmacılara yurtdışında iş verilmesi, işletmelerin ve diğer kurumların özelleştirilmesi, tasfiyesi, iflası vb. nedenler sayılabilir. Araştırmacıların sayısı düşerken kamu kurumlarında görevli öğretim elemanlarının sayısı az da olsa artmıştır. Kamu kurumlarındaki öğrenci sayısındaki artış oranı ise epeyce yüksektir. Makale Yeltsin döneminde bilim, araştırma ve Moskova'da Şarkiyat araştırmalarının durumunu hakkında katkı sağlamaktadır. Ayrıca uzun dönemde iki ülke Türklük araştırma kurumları ve araştırmacılarının ortak projelerine katkı sağlayacaktır.

Anahtar kelimeler: Yeltsin, Bilim, Araştırma, Türkiye birimi, Türkiye bilgini, Şarkiyat Enstitüsü, Moskova

\section{ABSTRACT}

The purpose of this research is to determine the status of science, research institutions, and researchers in the post-USSR Russian Federation. For the 
determination, the reports of official institutions, statistics of the Russian Federation Federal State Statistics Service, the statements of the academicians, the publications of the Oriental Institute, publications of the Institute for the Study of Science of the Russian Academy of Sciences (ISS RAS), the documentary prepared for the $200^{\text {th }}$ anniversary of the Oriental Institute, and the theses about Turkey registered in the Russian State Library were used. After determining the status of science, research institutions, and researchers in the USSR during the Yeltsin period, the place and role of the Oriental Institute Turkey unit in the Institute of Oriental Studies, the staff structure, the publications, the quality of the publications, the number of publications were determined. The influence of the RF administration on the research of the Turkey unit of the Institute of Oriental Studies of the Russian Academy of Sciences was evaluated. Research in the Soviet Union and the Russian Federation were not left to the usual flow and researchers did not follow an independent course. The structure and research of the Oriental Institute of Turkey unit were guided. Research institutions and researchers have been compared before and after the Yeltsin period. The number of employees working in research institutions was almost halved. The most important reasons for the decline in the number of employees are the non-payment of salaries, the decrease in salaries compared to the USSR period, the lack of opportunity and value to researchers, the employment of researchers abroad, the privatization, liquidation, bankruptcy of enterprises, and other institutions, etc. reasons can be listed. While the number of researchers decreased, the number of academic staff working in public institutions increased slightly. The rate of increase in the number of students in public institutions is quite high. This article contributes to the state of science, research, and Oriental studies in Moscow during the Yeltsin period. It will also contribute to the joint projects of Turkish studies institutions and research of the two countries in the long run.

Keywords: Yeltsin, Science, Research, Turkey unit, Turkey scholar, Oriental studies, Moskva

\section{EXTENDED ABSTRACT}

The transformation of Russia into an empire started with the annexation of a Turkish rooted society. Russia has grown by adding the countries, seas, and lands of Turkish rooted nations to its country for about 550 years. The joining of Turkish rooted societies to the Russian Empire, the increase in the number of Turks in Russia, and relations with Turkish-rooted independent societies formed the core of Orientalism. The Russian central government and local administrators had to learn Turkish and about Turks. Turkish studies in Russia was born with these needs.

Orientalism, Turkish studies, and Turkey studies in the USSR after the Russian Empire were shaped according to the priorities and needs of the USSR. The "Comintern school" was in favor of conducting research according to the goals of the USSR. Among the orientalists and Turkish researchers who grew up in the Russian Empire, those who did not comply with the USSR were subjected to the wrath of the administration. The structure and place of Turkish studies and Turkey studies was changed once again in the 1930s, the 1940s and the 1950s. There were different reasons for the corresponding change. Among these, the war, the demands of the KGB, the Foreign Ministry, and the Communist Party Central Committee have been influential.

After the USSR, the RF experienced an economic crisis. RF has proceeded to regulate its production and distribution structure according to the free market economy. There were problems in meeting the costs of science, research, and higher education institutions. Like all researchers, members of the Oriental Institute were also subjected to severe economic difficulties. Researchers went abroad with the hope of working and living in better conditions. 
The number of researchers that the RF took over from the USSR decreased by about half over time. Solzhenitsyn's description of the circumstance of science in RF is important. "For three hundred years in Russia, science has not been left to such neglect and poverty, ..." Soljenitsyn said.

The economic depression made it impossible for academic staff to survive with their salaries. The economic crisis increased diploma fraud. Due to the economic crisis, researchers worked in other public or private institutions besides the institutions they were assigned to. Researchers established private higher education units or worked in established private higher education units. The balance between the number of students and academic staff in higher education was disrupted. While the number of employees in RF higher education institutions increased slightly, the number of students increased remarkably. In these circumstances, the quality of teaching decreased.

Compared to the USSR, scientific and research institutions opened their doors abroad during the Yeltsin period. Collaborations increased. Researchers had a rare chance in the USSR era for research in Turkey. Compared to the USSR orientalists, research possibilities opened to Western Orientalists in Turkey. Furthermore, Western research institutions invited many researchers from Turkey. Few researchers were invited to the USSR from Turkey. Another shortcoming was the scarcity of researchers of Turkish origin working in the Turkey unit of the Oriental Institute. This situation could have been a conscious policy decision of the administration of the USSR or the administration of the Oriental Institute.

Compared to the USSR, during the Yeltsin period, researchers from Turkey and the number of students in the RF increased. For the first time, a Turkish citizen prepared a thesis at the Oriental Institute. The number of theses prepared by Turkish citizens at the Oriental Institute increased. Despite this positive trend, bilateral relations, bilateral research, and publications were insufficient during the Yeltsin period.

Despite some differences, the aims of Western and Russian Orientalism, Oriental studies and publications were similar. That similarity was having authority over the Orient. Said's determination was partially correct even for the Russian Empire, the USSR, and the Yeltsin period. ${ }^{1}$

The colonialists succeeded in imposing local (oriental) researchers to the mechanism of producing information in a manner suitable for the West, they followed a policy of research and knowledge production in line with their interests. ${ }^{2}$ The determination of Edward Said is also true for the USSR and partly for the RF. Said emphasized that knowledge production and dissemination is not objective but political.

Western Orientalism and Russian Orientalism are not exactly the same. The USA and the West saw the orient societies overseas separately and applied separate rules of law. For Russia (Russian Empire, USSR and RF) the east (orient) was also itself. Russia was adherent to the orient. The adherence was in the land and in the Russian soul. After the USSR, Russia called its own soul from the west. It did not come.

1 Edward W. Said, Orientalism, 1st ed. (London and Henley: Routledge \& Kegan Paul Ltd., 1978), 11.

2 Yücel Bulut, "Sunuş," Sosyoloji Dergisi 3, no. 24 (2012), 7-20. 


\section{Giriş}

Yeltsin döneminde Şarkiyat Enstitüsünü, Türkiye ve Türklük araştırmalarını ve araştırmacılarını anlamak için SSCB'den hatta Rusya İmparatorluğundan intikal eden mirası tetkik etmek gerekir. Öncelikle SSCB'de ve RF'de Türkiye araştırmaları ile Türklük araştırmaları birbirinden ayrılmıştır. Bu ayırım RF'na da intikal etmiştir. Liaisan Şahin Rusya'da Türk halkları bilimi, araştırmaları ile Anadolu Türkleri bilimi, araştırmaları ayrımını niteleyen terimlerin farklı olduğunu ifade etmiştir. Türkçede "Türk" terimi genel olarak Türk halklarını ve Anadolu Türklerini bildirir. Rusya'da (Rusya İmparatorluğu, SSCB ve RF) Şarkiyat biliminde тюрки [okunuşu: tyurki] Türk halklarını, турки [okunuşu: turki] ise Anadolu Türklerini ifade etmekte kullanılır. Rusya'da Türk halkları ile ilgili araştırmalar Tyurkologiya, Anadolu Türklerine ilişkin olanlar ise Turkologiya olarak tasnif edilmektedir. ${ }^{3} \mathrm{Bu}$ tasnife göre ayrılamayan araştırmalar ve araştırmacılar da vardır. Bazen kurumlar bazen araştırmalar bazen araştırmacılar hem Tyurkologiya özellikleri hem Turkologiya özellikleri göstermektedir. Şarkiyat Enstitüsünün 200'ncü yılı için hazırlanan belgeselin 6:47'nci saniyesindeki karedeki ses ayrıştırılamamıştır. Rusça “Т(ю)ркологический кабинет” mi yoksa Т(у)ркологический кабинет” mi ifadesinin seslendirildiği anlaşılmamaktadır. İngilizceye “Turcology chamber” olarak tercüme edilmiştir. Bu makalede coğrafyayı (Anadolu) değil Türk toplumunu araştıran bilim dalı Türklük araştırmaları/ Türkiyat/Türkoloji olarak ifade edilmektedir. Türklük bilimi/Türkiyat/Türkoloji bilim dalına katkı yapan araştırmacılar ise Türklük bilgini/Türkolog/Türkiyatçı olarak nitelenmektedir. Bazı araştırmalar ve araştırmacıların hatta kurumların ayrıştırılması (Türkiye araştırması ya da Türklük araştırması, Türkiye bilgini ya da Türklük bilgini, Türkiye araştırmaları kurumu/ birimi ya da Türklük araştırmaları kurumu/birimi) tasnifi gerekli veya mümkün olamamaktadır.

Moskova Büyük Knezliği, Rusya İmparatorluğu'nda toplanan bilgiler, verilen eserlerin Türklük bilimi başlığı altında toplanması daha doğru olur. Türklük biliminin doğuşuna ilişkin Smirnov,

\footnotetext{
"Düşmanlarını öğrenme isteği, Rus yönetimini, Türkler ve Kırım Tatarları hakkında özel olarak bilgi toplamak, bu amaç için onlara elçiler göndermek, Avrupa ülkelerinin Türklerle Tatarların tarihlerini, devlet yapılanmalarını ve dinlerini konu edinen yazılı kaynaklarıyla tanışmak zorunda bıraktı." demektedir. ${ }^{4}$
}

Rusya İmparatorluğu sonrası SSCB’nin ilk yıllarında Vasiliy Vladimiroviç Barthold'un (Васи́лий Влади́мирович Барто́льд) ӧncülüğüyle Şarkiyat Enstitüsünde “Туркологический кабинет" Türkiye bilimi kabini/odası/birimi 1927'de oluşturulmuştur. ${ }^{6}$ Barthold'un araştırma

3 Şahin Liaisan, "Geçmişten Bugüne Rusya'da Türkiye Araştırmaları," Türkiye Araştırmaları Literatür Dergisi 8, no. 15 (2010): 645-96, 645.

4 Mustafa Özbaş, "Rus Şarkiyat Çalışmalarının Temelleri Rus Tarihinin Başlangıcından 15. Yüzyıla Kadar," Türk Dünyasl İncelemeleri Dergisi 9, no. 2 (2009): 147-53, 149.

5 Кононов А. Н., “Тюркология // Азиатский Музей.”, 413.

6 Ю. А. Ли and С. Ф. Орешкова, Сектор Туриии Института Востоковедения РАН (Москва: Институт востоковедения РАН, 2009), 21. 
konuları ve eserleri Şarkiyat Enstitüsünün Türkiye biriminde görevli araştırmacıların eserlerini karşılaştırmakta fayda vardır. Barthold, Türklük araştırmacısı, Türklük bilgini iken Şarkiyat Enstitüsü araştırmacıları genelde Türkiye araştırmacıları mensup oldukları birimlerinin adı zamanla değişse de genelde adında Türklük/Türkiyat/Türkoloji değil Türkiye tercih edilmiştir. Günümüzde de Türklüğe değil coğrafyaya işaret eden "Сектор Турции” "Türkiye Sektörü/ Türkiye'nin Sektörü” adlandırması kullanılmaktadır.

Rusya'da Şarkiyatçılığın, Türklük biliminin başlangıcı Rusya devletinin kuruluşuna kadar geri götürülür. Mustafa Özbaş’a göre Şark1, Türkleri bilme, öğrenme ihtiyacı Rusya'nın doğuşuna, 9. yüzyıla kadar geri götürülür. Özbaş’a göre Şark’ı bilmek erken Rusya için bir seçim değil zorunluluktu. Erken Rusya'da tercümanlık yapanların muhtemelen Türkler ve Tatarlar olduğu iddia edilir. ${ }^{7}$ Yüzyıllarca Rusya'dan Şark'a gelip gidenler, Şark’tan gelen bilgiler, eserler, mallar sonrası Şark'a dair bir araştırma, toplama, koleksiyon ve sergileme kurumu 19. yüzyılın başında tesis edilmiştir. 19. yüzyılda “doğu” denilince sadece Rusya'nın doğusunda kalan topraklar değil, Mağrip ve Ortadoğu ülkeleri de kastedilmekteydi. Bunun sebebi Rusya şarkiyatçılığının müesseseye dönüşümünde Batı, Alman şarkiyatçılarının rolüdür.8 "Osmanlıcayı öğretmeye başlayan ilk kurum, 1823'te iki yıllık kurs şeklinde kurulan ve sınırlı pratik amacı olan (Türkiye ve İran'daki Rus elçiliklerine tercüman hazırlamak) St. Petersburg' daki Dışişleri Bakanlığı Asya Dairesi'ne bağlı Doğu Dilleri Eğitimi Bölümü'dür." Osmanlıcayı öğretmeye ilk başlayan kurumun Dışişleri Bakanlığı olması dikkat çekicidir. Rusya İmparatorluğunda Şarkiyat ve Şarkiyatçılığın genelde devlet ihtiyaçlarına göre şekillendirildiğine bir örnektir. Bu şekillendirmeme SSCB'de bilime, araştırmacılara müdahale şeklini almıştır. RF' de de devam etmektedir.

\section{Şarkiyat Enstitüsü Türkiye Kabinesinin (Bölmesi/Kabini/Odası) Oluşturulması ve Dönüştürülmesi}

Türkiye Kabinesinin oluşumu SSCB yöneticilerinin Şarkiyatçıları Sovyet yönetimine riayete zorladığı yılların başına isabet eder. Şarkiyat Enstitüsünde Türkiye araştırmaları (bazen Türklük) ayrı bir birim tesisi, mekân değişimi, Türkiye ve/veya Türklük araştırmacılarının siyasi yıldırma hatta şiddete maruz bırakılması süreci yaklaşık 100 yıl öncesine gider. Şarkiyatçılara, Türkiye ve/veya Türklük araştırmacılarına özgür çalışma ortamı sunulmayıp 1920'li ve 1930'lu yıllardan başlamak üzere Şarkiyatçılar, Türkiye ve/veya Türklük araştırmacıları tacize, sürgüne, tutuklanma, angarya ve infaza uğratılmıştır. ${ }^{10} \mathrm{Bu}$ yıllarda sadece şarkiyatçılar, Türkiye ve/veya Türklük araştırmacıları değil sanatçılar, edebiyatçılar da mağdur edilmiştir.

7 Mustafa Özbaş, "Rus Şarkiyat Çalışmalarının Temelleri Rus Tarihinin Başlangıcından 15. Yüzyıla Kadar.”, 153.

8 İhsan Çomak, "Vasili Dimitriyeviç Smirnov (1846-1922)," Uluslararası Sosyal Araştırmalar Dergisi 5, no. 21 (2012): 278-84, 279.

9 Şahin Liaisan, “Geçmişten Bugüne Rusya'da Türkiye Araştırmaları.”, 654.

10 Michale Kemper, "Introduction Integrating Soviet Oriental Studies," in The Heritage of Soviet Oriental Studies, ed. Michale Kemper and Stephan Conermann, n.d., 1-25, 8. 
“... 20'li yıllardan itibaren başta Lenin ve Stalin olmak üzere liderler ve yönetim kadrosu edebiyata yön vermeye, onu kendi arzu ve istekleri doğrultusunda kullanmaya çalışırlar. Kimi yazarlar yönetimin etkisi altına girmeyi kabul ederken kimileri ona karşı bir tutum takınırlar. Karşıt yazarlar içinse farklı uygulamalarla yıldırma politikası izlenir.” "... "Sanat sanat içindir", "Sanat toplum içindir" önermelerine bir yenisi de bu yıllar da eklenir: "Sanat propaganda içindir". ${ }^{11}$

Rusya İmparatorluğu sonrası SSCB şarkiyatının teşkilat düzeni, mekânı birkaç kez değiştirilmiştir. 1930'da Komünist Parti, şarkiyat araştırmalarının akademi, hükümet ve parti kurumlarınca yürütülmesi yerine Asya Müzesi, Doğu Bilimciler Derneği, Budist Kültürü Enstitüsü ve Türkiye bilimi odası birleştirilerek, Leningrad'da Bilimler Akademisinin Şarkiyat Enstitüsü (IVAN) kurulmasını kararlaştırmıştır. ${ }^{12} 1934$ 'te Bilimler Akademisi Moskova'ya nakledilse de Şarkiyat Enstitüsü Leningrad'da kalmıştır. II. Dünya Savaşı esnasında Şarkiyat Enstitüsü Taşkent'e nakledilmiştir. SSCB Bilimler Akademisi Başkanlığı'nın 28 Aralık 1943 tarihli kararı ile SSCB Bilimler Akademisi Moskova Bilimler Akademisi grubu kurulmuştur. ${ }^{13}$

Ekran alındısı 1: Şarkiyat Enstitüsünün 200'ncü Yılı İçin Hazırladığı Videoda Türkiye bilimi odası

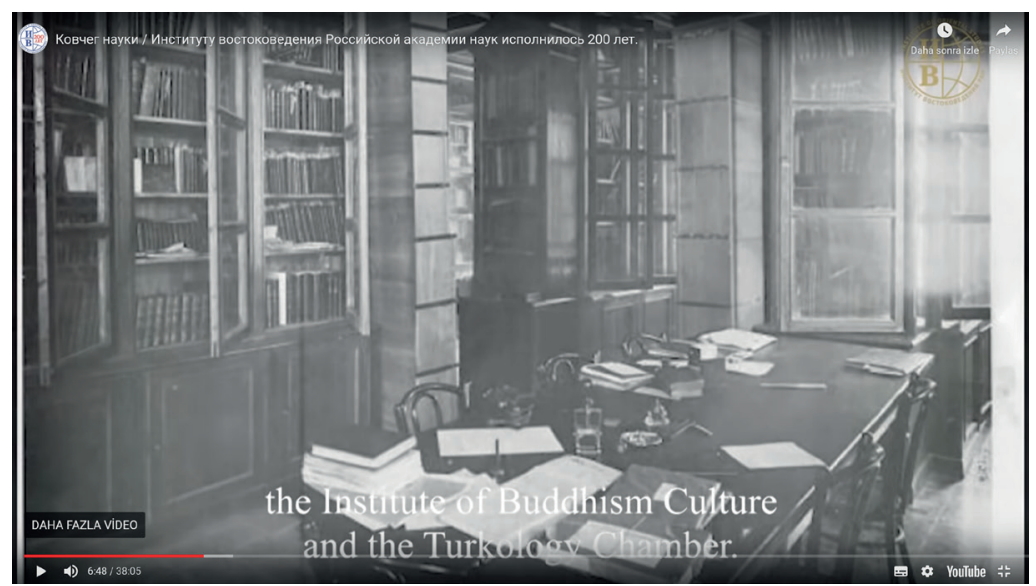

Kaynak: https://youtu.be/XHekOu2Q18g Ковчег науки / Институту востоковедения Российской академии наук исполнилось 200 лет (Kovcheg nauki / Institutu vostokovedeniya Rossiyskoy akademii nauk ispolnilos' 200 let). Erişim 28 Temmuz 2020.

11 Yasemin Gürsoy, Sovyet Dönemi Rus Edebiyatı (1953-1991) (İksad, 2018), 3-4.

12 Şahin Liaisan, “Geçmişten Bugüne Rusya’da Türkiye Araştırmaları.”, 666.

13 Ли and Орешкова, Сектор Турции Института Востоковедения РАН., 22. 
Ekran alındısı 2: Şarkiyat Enstitüsünün 200'ncü Yılı İçin Hazırladığg Videoda SSCB yönetiminin şarkiyatçıları katli, sürgünü
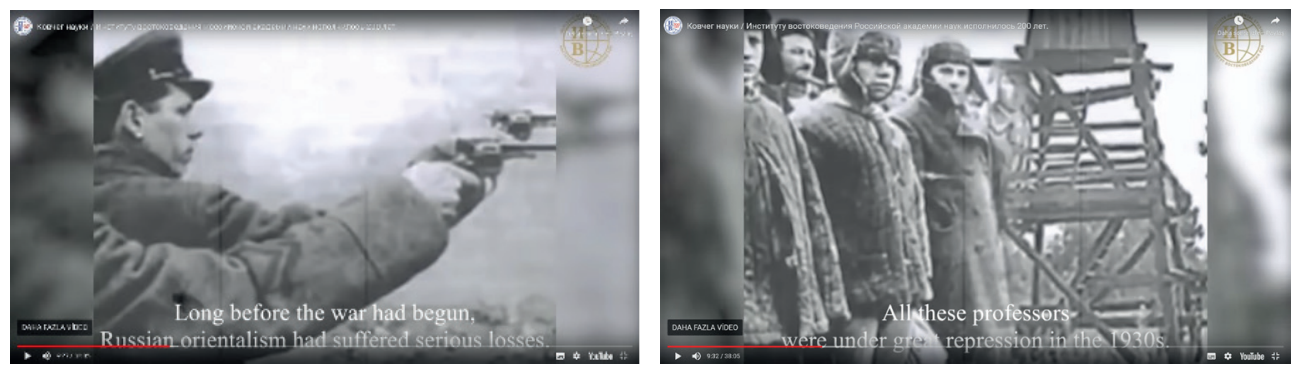

Kaynak: https://youtu.be/XHekOu2Q18g Ковчег науки / Институту востоковедения Российской академии наук исполнилось 200 лет (Kovcheg nauki / Institutu vostokovedeniya Rossiyskoy akademii nauk ispolnilos' 200 let). Erişim 28 Temmuz 2020.

Şarkiyat Enstitüsünün 200'ncü yılı için hazırladığı videoda SSCB Şarkiyatçılığına ciddi kayıplar yaşatıldığı belirtilmiştir. Şarkiyatçılar ağır şiddet görüp, Şarkiyatçılık küçük burjuvazi, kapalı, seçkinci bir bilim dalı olarak yaftalanmıştır. Sovyet yönetimi şarkiyatçılıkta burjuvazi etkisinin varlığını iddia etmiştir. Aslında bu iddia tüm bilim ve sanat, edebiyat dalları için de geçerlidir. Bu siyasi, ideolojik, zorba, müstebit ortamda Türkiye araştırmacıları ve/veya Türklük araştırmacılarının sayısı arttırılsa da hem Şarkiyat hem Türkiyat gerilemiştir.

1934 'te bilimler akademisi Moskova'ya nakledilmiş ancak Şarkiyat Enstitüsü Leningrad'da kalmıştı. SSCB Bakanlar Kurulu kararı ve SSCB Bilimler Akademisi Başkanlığı’nın 1 Haziran 1950 tarihli kararnamesine göre Şarkiyat Enstitüsü'nün Leningrad'dan Moskova'ya nakli öngörülmüştür. Yer değişiminden başka 1950'li yıllarda Şarkiyat Enstitüsünün yapısı tekrar değiştirilmiştir. Yapı, yer değişimlerinin farklı gerekçeleri vardır. Bazen kişisel, bazen savaş, bazen KGB, Dışişleri Bakanlığı ve Komünist Partisi Merkez Komitesi’nin talebiyle vd. gerekçeler. ${ }^{14}$ Şarkiyat Enstitüsünde Türkiye kabininin (odası) 1927'de oluşturulmasından yaklaşık 30 yıl sonra Moskova'da Şarkiyat Enstitüsünün Türkiye Sektörü 1956'da oluşturulmuştur. Yine 1956' da Şarkiyat Enstitüsünün Leningrad Şubesinde Türk-Moğol birimi oluşturulmuştur. ${ }^{15}$ Leningrad Şubesi ağırlıklı olarak Eskiçağ ve Ortaçağ tarihiyle ilgilenirken Moskova, merkez güncel sosyoekonomik meselelere, Türkiye bilimine, Türkiye'yi bilmeye yoğunlaşmıştır. ${ }^{16}$

1950'li yıllarda SSCB yönetiminin Türkiye ve Türklüğe bakışını yansıtması açısından Büyük Sovyet Ansiklopedisi önemlidir. 1950'li yıllarda yazılan SSCB toplumuna hitap eden Büyük Sovyet Ansiklopedisinde Türkler ve Türkiye başlığının kapsamı ve boyutu düşündürücüdür; “.... ansiklopedide Türklere ilişkin maddelerin yeterince ayrıntılandırılmamış olduğunu söylemek mümkündür. Yaklaşık 40.000 sayfanın olduğu ansiklopedide Türkler başlığının toplamda bir sayfa, Türkiye maddesinin ise 28 sayfa olması bunu doğrular niteliktedir. ...". ${ }^{17}$

14 Ли and Орешкова., 30.

15 https://bsv.ivran.ru/sektor-turcii Erişim 16 Temmuz 2020.

16 Şahin Liaisan, “Geçmişten Bugüne Rusya'da Türkiye Araştırmaları.”, 670.

17 Yevgeniya Sharlak, "Büyük Sovyet Ansiklopedisi’nde Türkler” (T.C. Ankara Üniversitesi Sosyal Bilimler Enstitüsü Tarih Bölümü (Genel Türk Tarihi) Anabilim Dalı, 2017)., 133. 
Rusya İmparatorluğu ve SSCB dönemindeki Türklük, Türkiye araştırmaları araştırmamızın odağında olmadığından genel bir hatırlatma yararlı görülmüştür. Kısaca SSCB döneminde Şarkiyat araştırmaları enstitüsündeki Türklük araştırmaları 19. yüzyılın parlaklığına erişememiştir. SSCB sonrası RF'de yaşanan keşmekeş, bilim ve yükssek öğrenimin olumsuz şartlarında daha da gerilemiştir.

\section{Yeltsin Döneminde Bilim ve Yükseköğrenim}

Rusya tarihinde Yeltsin dönemi geçiş dönemidir. Her alanda olduğu gibi geçiş bilimler akademisinde de yaşanmıştır. 21 Kasım 1991'de Rusya Federatif Sovyet Sosyalist Cumhuriyeti başkanı Boris Nikoloviç Yeltsin'in imzaladığı bir kararname ile SSCB Bilimler Akademisi, Rusya Bilimler Akademisine dönüştürülmüştür. ${ }^{18}$ Sosyalist cumhuriyetlerin oluşturduğu devletler ve toplumlardan Rusya Federasyonu'na geçişin yaşattığı karmaşa SSCB'den devir alınan kurumlara ve vatandaşlara yansımıştır. Araştırma kurumları ve araştırmacılar SSCB'den RF'ye geçişin sancılarını yaşamışlardır. Benzer sancılar Rusya İmparatorluğundan SSCB'ye geçerken de yaşanmıştır.

SSCB'den RF'ye geçiş RF vatandaşlarının hepsiyle birlikte araştırmacılara da sıkıntılı yıllar yaşatmıştır. Araştırmacılar işsiz kalmış, maaşları vaktinde ödenmemiş, maaşlarıyla alabildikleri mal ve hizmetlerin miktarı enflasyon nedeniyle azalmıştır. Araştırmacılar gösteriler, açlık grevleri ile RF yöneticilerinden maaşlarının ödenmesini temin edebilmiştir. Örneğin 8 Mart 1996'da Rusya Bilimler Akademisi başkanı Valary Sobolev araştırmacıların maaş ve ücretlerinin 2 aydır ödenmediğini bildirmiştir. Sendika başkanı 1996 yılı için önerilen bütçeye itiraz etmiştir. Başkan önerilen bütçenin kabulü halinde protesto ve grevlerin artacağı uyarısında bulunmuştur. Bilime ayrılan payın 1990 ile karşılaştırıldığında 1/15'e gerilediği belirtilmiştir. Sobolev gençlerin bilimi terk ettiğini bildirmiştir. 30 yaş altı bilim çalışanlarının oranının \% $\%$ 'e gerilediğini, RF yönetiminin araştırmacılara yeterince bütçeden pay ayırmadığından RF'nin dünya derecesinin ve itibarının azaldığını belirtmiştir. 1996'da ortalama 63,2 dolar olan maaş RF'de araştırmacıların iktisadi durumuna ilişkin fikir verebilir. ${ }^{19}$

1996'da seçimler öncesinde Yeltsin bilime ilişkin kararnameler imzalamıştır. Yeltsin "Rusya Federasyonu'nda Temel Bilimlerin Kalkınması ve Rusya Bilimler Akademisin Statüsü" başlıklı kararnameyi 15 Nisan 1996'da imzalamıştır. ${ }^{20}$ Yeltsin "Rusya Biliminin Kalkınması Hakkında Doktrin” başlıklı kararnameyi 13 Haziran 1996' da imzalamıştır. ${ }^{21}$ İki kararnamede de kalkınmak, ilerletmek, geliştirmek (развить) olarak tercüme edilen fiilin kullanımı Yeltsin döneminde bilim alanında bir sorun olduğunun emaresidir.

Nisan ve Haziran aylarındaki kararnamelerden araştırmacılar memnun olmamıştır. Ekim

18 Stephen Fortescue, "The Russian Academy of Sciences and the Soviet Academy of Sciences: Continuity or Disjunction?," Minerva, no. 30 (1992): 459-78, 459.

19 Judith Perera and Andrei Ivanov, "RUSSIA-SCIENCE: An End to Science?," 1996, http://www.ipsnews. net/1996/03/russia-science-an-end-to-science/.

20 http://www.kremlin.ru/acts/bank/9204 erişim 09 Ağustos 2020.

21 http://www.snto.ru/chto/upload/pdf/GNTP_05.pdf erişim 09 Ağustos 2020. 
1996'da Strakhov 4 aydır maaşlarının ödenmediğinden yakınmıştır. RBA’nin 336 enstitüsünde 122.000 çalışanın maaşının ödenmediğini, bilim dışında başka işler yaparak hayatta kalmaya çabaladıklarını belirtmiştir. ${ }^{22} 10$ Ekim 1996'da RBA'nın yaklaşık 300 enstitüsünde çalışan yüzlerce araştırmacı ücretlerinin ödenmesinin gecikmesini protesto etmek için sokaklara çıkmıştır. ${ }^{23}$

1990’lı yıllardaki sıkıntılar akademi mensuplarınca düzenlenen sahte diploma sayısını arttırmış, diploma almaya hak kazanma standartlarını düşürmüştür. Sovyet döneminde sahte diploma ya da yüksek öğrenime kabul sırasında para ile öne geçirilme, sınavlarda para karşılı̆̆ başarılı sayılma vakaları yaşansa da oranı düşük iken Yeltsin döneminde sahte ya da tahrif edilmiş akademik belgelerin oranı artmıştır. Sahtecilik devlet eliyle, devletin bilgisi dahilinde yapıldığı gibi çalışanların şahsi menfaatleri için de yapılmıştır. Devlet eliyle yapılan sahteciliğe örnek olarak SSCB döneminde KGB'nin sahte Şarkiyat diplomasıyla Asildar Guseynov'u istihbarat toplamak için Türkiye'ye göndermesi gösterilebilir. TASS muhabiri kimliği ve sahte Şarkiyat diploması istihbaratçıya paravan olmuştur. ${ }^{24}$ Yeltsin döneminde ticari maksatlı sahtekârlık çok artmıştır. Şahsen 2000 yılında Moskova metrosunda ellerinde yazılarla dolaşanlar dikkatimi çekmiştir. Ellerinde “диплом” yazısıyla dolaşanların diploma satın almak isteyenlere erişmeye çabaladıkları anlaşılıyordu.

RF'den alınan sahte diplomalar Türkiye'ye ve farklı ülkelere dağılmıştır. T.C. Moskova Büyükelçiliği Eğitim Müşavirliğinin bir görevi de sahte ile gerçek diplomaları tespit edip Türkiye'deki ilgili kurumları bilgilendirmekti. Eğitim Müşavirliği 1994'te faaliyete geçmiştir. Eğitim Müşaviri RF'de eğitim, araştırma yapan T.C. vatandaşlarına hizmet vermenin, RF'den Türkiye'ye gidecek öğrenci ve araştırmacılara erişmenin, teşvik etmenin yanında RF'den alınan Türkiye'deki resmi birimlere sunulan diplomaların gerçekliğini araştırmakla görevliydi. RF'den alınan sahte diplomalar sadece Türkiye'ye değil birçok ülkeye girmiştir. Esa Antero Laiho sadece bir vakıdar. ${ }^{25}$ Diploma satışı Yeltsin döneminde, geride kalmamıştır halen devam etmektedir. Metroda dolaşarak değil internet üzerinden diploma satışı yapılmaktadır. Halen http://vuzdiplom.ru/ açıldığında "Как купить диплом о высшем образовании - быстро и с гарантией” yazısı (“Hızlı ve garantili Yükseköğrenim diploması nasıl satın alınır?”) ile karşılaşıyoruz.

RF'de bilim mensuplarının sıkıntıları Yeltsin'in 1996'da tekrar seçilmesi sonrası da süregitmiştir. Yeltsin yönetiminin bilime yaklaşımını anlamak için sanırım Soljenitsin'den tek cümlelik aktarım yeterlidir. Aleksandr İsayeviç Soljenitsin 1998'de "Rusya Bilimler Akademisi

22 Judith Perera, "Russia's Scientists Take to the Streets," NewScientist, 1996, https://www.newscientist.com/ article/mg15220521-300-russias-scientists-take-to-the-streets/.

23 https://www.sciencemag.org/news/1996/10/russian-scientists-protest-money-woes erişim 07 Ağustos 2020.

24 Svetlana Turyalay, "Türkiye Az Kalsın Sovyetlere Nasıl Dahil Oluyordu. Eski KGB Elemanlarının İfadeleri," Komsomolskaya Pravda, July 26, 1995.

25 https:/www.yenisafak.com/saglik/sahte-doktor-oldurdu-604845 Erişim 09 Ağustos 2020, https://www.61 saat. com/sahte-universite-diplomalari-makale,2212.html Erişim 09 A ğustos 2020 https://www.ncbi.nlm.nih.gov/ pmc/articles/PMC1169423/ Erişim 09 Ağustos 2020. 
Büyük Lomonosov Madalyası" takdimi törenindeki hitabında "Rusya' da üç yüz yıl boyunca bilim bu kadar ihmal ve yoksulluğa terk edilmemiştir.” cümlesiyle Yetsin yönetiminin bilime yaklaşımını özetlemiştir. ${ }^{26}$

SSCB sonrası Yeltsin yönetiminde araştırmacılar RF'den göç etmek zorunda kalmıştır. Daha çok maaş ve daha iyi çalışma ortamı arayışındaki 80 bin araştırmacı RF'yi terk etmiştir. Araştırmacılar kötü çalışma şartları, bürokrasi ve köhnemiş sistem yüzünden ülkeyi terk etmiştir. Mikhail Delyagin'e göre Rusya'daki enstitülerde çalışan bilim adamları, kendilerini, ne dediklerini bilmeyen cahiller için çalışan köleler olarak görüp, 20'nci, hatta 19'uncu yüzyıla gerilediklerini düşünüyorlard $1{ }^{27}$ Aslında 19. yüzyıla gerileseler iyidir. 19. yüzyılda araştırmacılara, bilginlere değer ve para veriliyordu. Rusya'yı terk edebilen araştırmacılar arasında Yahudi asıllılar oldukça fazlaydı. Aslında bilim, bilgi, bilginler Rusya İmparatorluğu'na yüzyıllar boyunca göç etmiş, bilim ithal edilmiştir. İthal edildiğine göre daha fazla ilgi, itibar, para verilmiş olmalıdır. Milliyetlerine göre bilginlere, araştırmacılara baktığımızda Rusya İmparatorluğunda Alman asıllı araştırmacılar önde geliyordu. Asya Müzesinin ilk yöneticileri Alman kökenliydi. ${ }^{28}$ Devrim sorası Almanların yerini Yahudi asıllı Sovyet yurttaşları aldı. Yahudiler Rusya İmparatorluğunu yıkan devrimde de en önde yer almışlardı. SSCB sonrası RF'de Yahudilerin yerini kısmen Ermeniler aldı. ${ }^{29} 1920$ 'li yılların ortalarında parti kadrolarının "Yahudileştirilmesine" tezat olarak "Ruslaştırılma" politikası başlatılmıştır. Politbüro içindeki Yahudi liderler 1927'den itibaren uzaklaştırılmıştır. Bu durum anti-semitist değil, parti kadrolarında yapılan basit bir değişiklik olarak tanımlanmıştır. ${ }^{30}$ Halen Yahudi asıllıların RF yönetimine ve bilimine katkıları sürmektedir.

SSCB'nin dağıtılma nedenlerini, SSCB sonrası Şarkiyat Enstitüsü ve mensuplarının durumunu anlamak için Şarkiyat mensuplarının değerlendirmelerini aktarmakta fayda vardır. Şarkiyat Enstitüsü’nden Prof. Robert Landa'nın ${ }^{31}$ SSCB'nin dağıtılması ve Şarkiyat Enstitüsünün durumu hakkındaki görüşleri dikkate değerdir. Landa'ya göre;

“SSCB'yi ve sosyalizmi yıkılışa sürükleyen ... Yüksek mevkilerde bulunan, ama bir ideale ve ülkelerine hizmet etme isteğinden daha çok, kişisel yükselme ve zenginleşme tutkusuyla öne firlayanların devrimi. ... halkın yoksun kaldığı bazı 'ayrıcalıklar'dan (henüz diledikleri kadar yeterli değildi) yararlanmakla birlikte yine de talihlerinden hoşnut değildiler. ...

26 http://vivovoco.astronet.ru/VV/PAPERS/ECCE/VIETSOLJ.HTM Erişim 07 Ağustos 2020. Нitap “Независимой газета" 3 Haziran 1999 tarihli sayısında yayımlanmıştır.

27 https:/www.amerikaninsesi.com/a/a-17-2010-03-02-voa2-88926702/882376.html 02 Mart 2010 Erişim 07 Ağustos 2020.

28 https://youtu.be/XHekOu2Q18g 10:00’ncı dakika Erişim 09 Ağustos 2020.

29 Развал советской науки, https://ruxpert.ru/\%D0\%A0\%D0\%B0\%D0\%B7\%D0\%B2\%D0\%B0\%D0\%BB

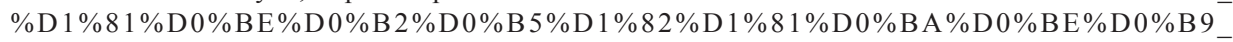
$\% \mathrm{D} 0 \% \mathrm{BD} \% \mathrm{D} 0 \% \mathrm{~B} 0 \% \mathrm{D} 1 \% 83 \% \mathrm{D} 0 \% \mathrm{BA} \% \mathrm{D} 0 \% \mathrm{~B} 8 \#$ cite_note-.D0.9F.D0.B0.D0.B2.D0.BB.D0.BE.D0.B2-6 Erişim 07 Ağustos 2020.

30 Merve Suna Özel, "Stalin Dönemi Rus Milliyetçiliği ve Politikaları,” Kırıkkale Üniversitesi Sosyal Bilimler Dergisi 4, no. 2 (2014): 99-122, 112.

31 Bkz. https://www.ivran.ru/persons/RobertLanda Erişim 09 Mart 2020. 
Kendilerini tamamen güvencede hissedecekleri, istedikleri gibi serpilebilecekleri bir konumda bulunmak için aceleleri vardı. ... İstedikleri şey 'tam özgürlüktü; yani çok çabuk zenginleşme, satın alma, satma, kendi hesaplarına iş çevirme, şimdiye kadar yasak olan işlere atılma, denetimsiz ve siyasi ya da ahlaki hiçbir engel olmaksızın kaçakçılık etmekti. Böyle bir ruh hali toplumumuzun içinde bulunduğu bunalım durumunu dile getiriyordu; ..." ${ }^{\prime 2}$

Profesör Landa yöneticilerin, ayrıcalıklarını arttıramadıkları için SSCB'den hoşnut olmadıklarını iddia etmiştir. SSCB döneminde ayrıcalıklı nomenklatura mensupları içinde SSCB Bilimler Akademisi mensupları da sayılabilir. Nomenklatura mensupları imtiyaz ve muafiyetlerden, yüksek maaşlardan RF döneminde mahrum kaldıkları için genelde SSCB dönemine olumlu bakmışlardır. Aslında bir ülkenin refahında ya da yoksulluğunda toplumu yönetenlerin ve yöneticileri eğiten, topluma yol göstermesi beklenenlerin, araştırma mensuplarının payı yüksektir. Bu manada SSCB’nin iktisadi başarısızlığında araştırmacıların, akademi mensuplarının tesiri hususunu irdelemek gerekebilir. SSCB yöneticileri araştırmacılardan, akademi mensuplarından, sanatçılardan ve edebiyatçılardan rejime destek, rejimi meşrulaştırmalarını beklemişlerdir. Araştırmacılar, sanatçılar, edebiyatçılar yöneticilerin korkusundan, gazabından çekindiklerinden gerçeklikten, müspet bilimden ${ }^{33}$, tarafsız sanattan (ideolojik olmayan) ve edebiyattan uzaklaşmışlardır. Korkmayan, çekinmeyenler sansüre maruz kalmışlardır. ${ }^{34} \mathrm{Bu}$ durumu açıklamada Leyla Tağızade'nin tespitleri dikkate değerdir: “... Değişmez gerçek olarak kabul edilen, şablonlaşmış cümlelerden oluşan bir alandı. Düşünülen değil, söylenmesi ve yazılması gereken şeyler söylenir ve yazılırdı. ..." ${ }^{35}$ SSCB araştırmacılarının, sanatçı ve edebiyatçılarının Sovyet başarısızlığındaki rolünü tam manasıyla belirlemek imkânsızdır. Çünkü araştırma, düşünce ve ifade özgürlüğü olmayan bir ortamda başarısızlıktaki paylarını, rollerini belirlemek muhaldir. Başarısılıkta payı olsun olmasın tüm araştırmacılar, sanatçılar, edebiyatçılar SSCB sonrasının sıkıntılarıyla baş başa kalmışlardır.

Henri Aleg'in izlenimleri ve adını vermediği bir Şarkiyat profesöründen aktardıkları Yeltsin dönemi yöneticilerinin araştırma kurumları ve araştırmacılara bakış açısını özetler mahiyettedir. Henri Aleg’e göre araştırmaya ayrılan binalar bakanların, yüksek memurların, başbakana erişebilen spekülatör, gangster ve mafyanın gözünden kaçmıyordu. Şarkiyat Enstitüsü profesörlerinden biri Şarkiyat Enstitüsü binasının bir bölümünün bir bankaya kiralandığını, bitişik sokaktaki lokallerinin ise bir Japon iş adamının eline terk edildiğini belirtmişti. Henri

32 Henri Alleg, Büyük Geri Sıçrama Yıkıntı ve Umut Rusyasonda Röportaj, 2nd ed. (İstanbul: Evrensel Basım Yayın, 2013)., 170-171.

33 Trofim Lısenko hakkındaki anlaşmazlık dikkat çekicidir. ““'Lisenko Tartışması Üzerine” çalışmasıyla 1995 yılında konuya değinen Prof. Dr. Nihat Bozcuk, 1937-1964 arası dönemi Lısenko'dan ve yönetimin bilim üzerindeki etkilerinden dolayı "Sovyet genetiğinin çok garip ve acılı bir bölümü” olarak tanımlar." Yasemin Gürsoy Şumnulu, “Türk Kaynaklarında Trofim Lisenko,” in Процеси Украӥнського Держсавотворення Від Давніх Часів До Сьогодення (з Нагоди 1000-Річчя з Початку Правління Ярослава Мудрого) 18 Квітня 2019 Року (Ternopil, 2019), 66-69., 67.

34 1989'da sansür tamamen kaldırılmıştır. Gürsoy, Sovyet Dönemi Rus Edebiyatı (1953-1991)., 34, 113.

35 Leyla Tağızade, "Sosyalist Realizm: Kökeni, Oluşum Süreci ve Kavramı," Modern Türklük Araştırmaları Dergisi 3, no. 4 (2006): 7-24., 8. 
Aleg'in aynı profesörden Yeltsin döneminde yükseköğretim ve araştırmacıların durumunu yansitiyor;

"Eğitim ve araştırma için artık devletin parası yok. Bu ilgisizliğe karşı sesimizi yükselttiğimiz zaman, bakanlık, 'bugün yapılacak daha önemli işler var' diye karşılık veriyor. Bütün ülkede, yüzbinlerce işçi, memur ve askerin aldıklarından daha fazla ücret almayan profesör ve araştırmacılar bir de aylarca ücretlerinin ödenmesi için bekliyor. Üniversite yöneticileri dersleri ve araştırma çalışmalarını sürdürmek için kendilerine hiç değilse bir şeyler ödenmesini istedikleri zaman onlara şöyle karşılık veriliyor: 'Başınızın çaresine bakın!'. Başka bir deyişle, artık, yükseköğretim, bilimsel eğitim ve araştırmanın geleceği gündemde değil. Gündemde olan business ve dolar. Gerisi bizi ilgilendirmez! Bu durumda, üniversite ve enstitülerin yönetiminden doğrudan doğruya sorumlu olanlar, 'başlarının çaresine bakıyorlar'. Bundan dolayı da kimse kınayamaz onlar1. ${ }^{" 36}$

Tablo 1: Yeltsin döneminde RF'de Yükseköğretim kurumları sayısı, 1993-2000

\begin{tabular}{|l|c|c|c|c|c|} 
& $\mathbf{1 9 9 3 / 9 4}$ & $\mathbf{1 9 9 5 / 9 6}$ & $\mathbf{1 9 9 7 / 9 8}$ & $\mathbf{1 9 9 8 / 9 9}$ & $\mathbf{1 9 9 9 / 2 0 0 0}$ \\
\hline $\begin{array}{l}\text { Toplam yükseköğretim } \\
\text { kurumu sayısı }\end{array}$ & 626 & 762 & 880 & 914 & 939 \\
\hline Kamu & 548 & 569 & 578 & 580 & 590 \\
\hline Kamu harici & 78 & 193 & 302 & 334 & 349 \\
\hline Toplam öğrenci sayısı & 2.613 .000 & 2.791 .000 & 3.248 .000 & 3.598 .000 & 4.073 .000 \\
\hline $\begin{array}{l}\text { Kamu kurumlarındaki } \\
\text { öğrenci sayısı }\end{array}$ & 2.543 .000 & 2.655 .000 & 3.046 .000 & 3.347 .000 & 3.728 .000 \\
\hline
\end{tabular}

Kaynak: Россия В Цифрах, 2003, sf. 123.

Tablo 2: Yeltsin dönemi öncesi ve Yeltsin döneminde yükseköğrenim kurumları ve öğrenci sayıs1, 1914-2000

\begin{tabular}{|l|c|c|c|}
\hline Yıllar & $\begin{array}{c}\text { Yükseköğretim kurumu } \\
\text { sayısı }\end{array}$ & $\begin{array}{c}\text { Öğrenci sayısı, 1.000 } \\
\text { öğrenci }\end{array}$ & $\begin{array}{c}\text { Her 10 0000 nüfusa } \\
\text { tekabül eden öğrenci } \\
\text { sayısı }\end{array}$ \\
\hline 1914 & 72 & 87 & 10 \\
\hline 1917 & 150 & 149 & 16 \\
\hline 1927 (15 Aralı̆̆a göre) & 90 & 114 & 0 \\
\hline $1940 / 41$ & 481 & 478 & 43 \\
\hline $1950 / 51$ & 516 & 797 & 77 \\
\hline $1960 / 61$ & 430 & 1497 & 124 \\
\hline $1970 / 71$ & 457 & 2672 & 204 \\
\hline $1975 / 76$ & 483 & 2857 & 212 \\
\hline $1980 / 81$ & 494 & 3046 & 219 \\
\hline
\end{tabular}

36 Henri Alleg, Büyük Geri Sıçrama Yıkıntı ve Umut Rusyasonda Röportaj, 25-26. 


\begin{tabular}{|l|l|l|l|}
\hline $1985 / 86$ & 502 & 2966 & 206 \\
\hline $1990 / 91$ & 514 & 2825 & 190 \\
\hline $1991 / 92$ & 519 & 2763 & 186 \\
\hline $1992 / 93$ & 535 & 2638 & 178 \\
\hline $1993 / 94$ & 626 & 2613 & 176 \\
\hline $1994 / 95$ & 710 & 2645 & 179 \\
\hline $1995 / 96$ & 762 & 2791 & 202 \\
\hline $1996 / 97$ & 817 & 2965 & 222 \\
\hline $1997 / 98$ & 880 & 3248 & 247 \\
\hline $1998 / 99$ & 914 & 3598 & 280 \\
\hline $1999 / 2000$ & 939 & 4073 & 189 \\
\hline
\end{tabular}

Kaynak: http://stat.edu.ru/scr/db.cgi?act=listDB\&t=2_6_1a\&ttype=2\&Field=All Erişim 18 Ağustos 2020.

SSCB döneminde eğitim, yükseköğrenim devlet tekelindeydi. Daha doğrusu SSCB'de Gorboçov dönemine kadar mal ve hizmetlerin tamamına yakınını kamu kesimi üretiyordu. Gorbaçov döneminde kanunlar değiştirilerek kısmen özel müteşebbislerin (gerçek ya da tüzel kişiler için) mal ve hizmet üretmeleri önündeki kanuni engeller kısmen kaldırıldı. Yeltsin döneminde fabrikalar, tesisler özelleştirildi. Eğitim tesisleri (enstitüler, üniversiteler) özelleştirilmese de müteşebbisler özel yükseköğretim kurumları kurdular. 1993'te 78 olan özel yükseköğretim kurumu sayısının katlanarak (4.5 kat) artarak 2000 yılında 349'a eriştiği görülüyor. Bu artış oldukça dikkat çekicidir. Kamu araştırma, yükseköğretim kurumlarından ayrılan ya da ayrılmadan hem kamu hem özel araştırma, yükseköğretim kurumlarında çalışan akademisyen kesimi ortaya çıktı. Örneğin Şarkiyat Enstitüsü ya da Moskova Devlet Üniversitesi Asya ve Afrika Ülkeleri Enstitüsü ${ }^{37}$ mensupları özel Uygulamalı Şarkiyat Enstitüsünde (Институт практического востоковедения) ders veriyordu. Yeltsin döneminde hem kamu hem özel yükseköğrenim kurumları standartlara, olması gerekenlere riayet etmedi/edemedi. Ancak denetim eksikliği ya da rüşvet ile uzun süre yükseköğretim kurumlarının faaliyetlerini sürdürmesine göz yumuldu. Örneğin Uygulamalı Şarkiyat Enstitüsünün ruhsatı 2014'te iptal edildi. İptal gerekçeleri dikkat çekicidir; ruhsatsız bölüm açmak, elektronik kayıt sisteminin olmaması, geçersiz (olması gerekenin aksi) belge düzenlemek, mecburi usulünce düzenlenmesi gereken kayıtların yokluğu. ${ }^{38}$

1993 ’te 548 yükseköğretim birimi sayısı 2000'de 607'ye çıkmıştır. 59 yeni yükseköğretim kurumu açılmıştır. Kamu yükseköğretim kurumlarındaki öğrenci sayısı 1993’te 2.613.000 iken Yeltsin döneminin sonunda 2000 yılında 3.728.000'e yükselmiştir. Yeltsin döneminin

37 2004-2005 yıllarında bu enstitüde Ankara Üniversitesinde görevlendirilerek araştırma ve uygulamalarda bulundum.

38 http://www.daokedao.ru/2014/08/18/institut-prakticheskogo-vostokovedeniya-lishen-litsenzii/ Erişim 10 Ağustos 2020 . 
başı ile kıyaslandığında sonunda öğrenci sayısının 1.115.000 arttığı görülüyor. Öğrenci sayısı artarken akademik personel sayısının durumuna bakmak gerekir. Yeltsin döneminin başında kamu kurumlarında görevli öğretim personeli sayısı yaklaşık 219.700 iken Yeltsin dönemi sonunda 247.500’e çıkmıştır. Öğrenci sayısındaki artış oranı ile karşılaştırıldığında öğretim elemanı sayısının yavaş arttığı görülür.

Tablo 3: Kamu kurumlarında görevli derce ve unvanlarına göre öğretim kadrosu sayısı, 1970-2000 (1.000 kişi)

\begin{tabular}{|l|c|c|c|c|c|c|c|c|c|c|}
\hline & $\mathbf{1 9 7 0 / 7 1}$ & $\mathbf{1 9 7 5 / 7 6}$ & $\mathbf{1 9 8 0 / 8 1}$ & $\mathbf{1 9 8 5 / 8 6}$ & $\mathbf{1 9 9 0 / 9 1}$ & $\mathbf{1 9 9 6 / 9 4}$ & $\mathbf{1 9 9 7 / 9 5}$ & $\mathbf{1 9 9 8 / 9 6}$ & $\mathbf{1 9 9 9 / 9 7}$ & $\mathbf{2 0 0 0 / 9 8}$ \\
\hline $\begin{array}{l}\text { Öğretim } \\
\text { kadrosu } \\
\text { sayıs1 (tam } \\
\text { zamanl1 } \\
\text { personel) - } \\
\text { toplam }\end{array}$ & 159,5 & 180,7 & 204 & 205,1 & 219,7 & 239,8 & 233,5 & 240,2 & 243 & 247,5 \\
\hline Derece & & & & & & & & & & \\
\hline $\begin{array}{l}\text { Bilim } \\
\text { doktoru }\end{array}$ & & 8,2 & 9,6 & 9,8 & 13,7 & 17,6 & 18,7 & 20,1 & 21,4 & 22,8 \\
\hline Bilim aday1 & & 76,1 & 92,4 & 103,6 & 115,2 & 117,4 & 114,6 & 117,5 & 118,5 & 119,1 \\
\hline $\begin{array}{l}\text { Öğretim } \\
\text { unvanı }\end{array}$ & & & & & & & & & & \\
\hline Profesör & & & & & 12,9 & 18 & 19,4 & 21,1 & 22,3 & 23,5 \\
\hline Doçent & & & & & 73,1 & 81,9 & 82,2 & 85,3 & 86,1 & 87,4 \\
\hline
\end{tabular}

Kaynak: http://stat.edu.ru/scr/db.cgi?act=listDB\&t=2_6_24\&ttype=2\&Field=All Erişim 11 Ağustos 2020.

Şekil 1: Yeltsin döneminde bilim çalışanları sayısı, 1992-2000, bin kişi

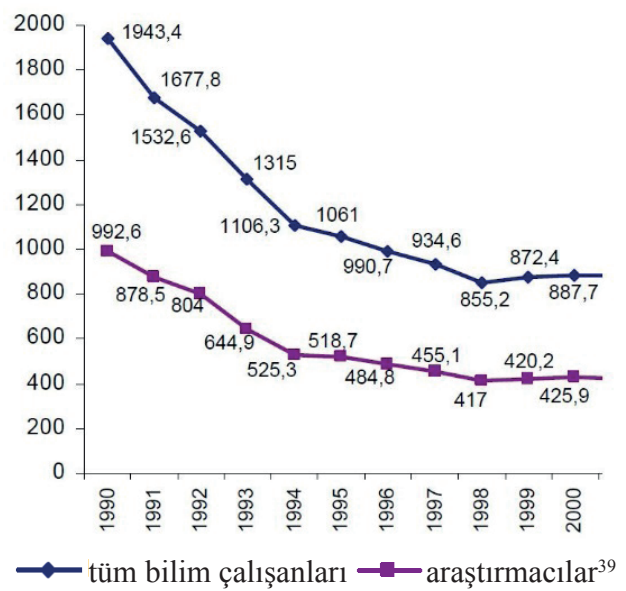

Kaynak: Миндели, Л. Э. Чистякова, В. Е. (2016) Структура и Динамика Кадрового Потенциала Российской Науки, ИПРАН РАН, Москва, с. 8.

39 Л. Э. Миндели and В. Е. Чистякова, Структура и Динамика Кадрового Потенциала Российской Науки (Москва: ИПРАН РАН, 2016), 8. 
Yeltsin döneminin başında 1991 'de bilim çalışanlarının sayısı 1.677.800 iken Yeltsin döneminin sonunda ${ }^{40} 872.400$ 'e gerilemiştir. Bilim çalışanlarının sayısı yaklaşık yarıya düşmüştür. RF'de bilim çalışanları özel ve kamu üniversiteleri, enstitüler, Rusya Bilimler Akademisi, işletmeler, gönüllü kuruluşlar arasında dağılıyordu. Kamu bilim çalışanlarının sayısı azalmasa da işletmelerdeki bilim çalışanlarının sayısı tasfiyeler, özelleştirmeler, iflaslar, ücretlerin ödenmemesi, yurt dışında daha iyi imkânlar vd. nedenlerden dolayı azalmıştır. RF araştırmacıları Türkiye'ye de gelmiştir. 2015/2016 yılı itibariyle Adıge Cumhuriyetinden 3, Çeçen Cumhuriyetinden 6, Tataristan Cumhuriyetinden 1, Rusya Federasyonundan 72 öğretim elemanı görev yapmaktayd1. ${ }^{41}$ Özel işletmeler vd. araştırma kurumlarında da RF'den gelip Türkiye'nin araştırma, geliştirme çalışmalarına katkıda yapanların sayısı bilinmemektedir.

\begin{tabular}{|c|c|c|c|c|c|c|}
\hline \multicolumn{2}{|c|}{ Tablo 4: Bilim, araştırma çalışanları, 1990-2000. ${ }^{22}$} \\
\hline Yıllar & $\begin{array}{c}\text { Tüm } \\
\text { çlışanlar }\end{array}$ & $\begin{array}{c}\text { Yıllık } \\
\text { değişim }\end{array}$ & $\begin{array}{c}\text { Araştırmacılar ve } \\
\text { teknik personel }\end{array}$ & $\begin{array}{c}\text { Yıllık } \\
\text { değişim }\end{array}$ & $\begin{array}{c}\text { Yardımcı personel } \\
\text { ve diğerleri }\end{array}$ & $\begin{array}{c}\text { Yıllık } \\
\text { değişim }\end{array}$ \\
\hline 1990 & 1943,4 & $-272,2$ & 1227,4 & $-161,7$ & 716,0 & $-110,3$ \\
\hline 1991 & 1677,8 & $-265,6$ & 1079,1 & $-148,3$ & 598,7 & $-117,3$ \\
\hline 1992 & 1532,6 & $-145,2$ & 984,7 & $-94,4$ & 547,9 & $-50,8$ \\
\hline 1993 & 1315,0 & $-217,6$ & 778,8 & $-205,9$ & 536,2 & $-11,7$ \\
\hline 1994 & 1106,3 & $-208,7$ & 640,8 & $-138,0$ & 465,4 & $-70,8$ \\
\hline 1995 & 1061,0 & $-45,3$ & 620,1 & $-20,7$ & 440,9 & $-24,5$ \\
\hline 1996 & 990,7 & $-70,3$ & 572,6 & $-47,5$ & 418,1 & $-22,8$ \\
\hline 1997 & 934,6 & $-56,1$ & 535,4 & $-37,2$ & 399,2 & $-18,9$ \\
\hline 1998 & 855,2 & $-79,4$ & 491,8 & $-43,6$ & 363,4 & $-35,8$ \\
\hline 1999 & 872,4 & $+17,2$ & 492,6 & $+0,8$ & 379,7 & $+16,3$ \\
\hline 2000 & 887,7 & $+15,3$ & 501,1 & $+8,5$ & 386,6 & $+6,9$ \\
\hline
\end{tabular}

Kaynak: Аллахвердян А. Г., Агамова Н. С. Российская наука в постсоветский период: от кадрового обвала к численной стабилизации // Наука та наукознавство. 2005. № 1., sf. 55-56.

Bilim, araştırma çalışanlarının 1990 sonrası 1999'a kadar sürekli azaldığı tablo 4 'te görülmektedir.

40 Yeltsin 31 Aralık 1991'de görevden ayrıldığını televizyondan beyan etmiştir.

41 Bkz. https://istatistik.yok.gov.tr/ Tablo 201. Yabanc1 uyruklu öğretim elemanlarının uyruğuna ve akademik görevlerine göre sayıları, 2015 - 2016, 3. (20.05.2016)

42 Н.С. Агамова А.Г. Аллахвердян, "Российская Наука в Постсоветский Период: От Кадрового Обвала к Численной Стабилизации,” Наука Та Наукознавство, по. 1 (2005): 51-62, 55-56. 
Tablo 5: Araştırma kurumlarında çalışanların dağılımı, 1994-1999.

\begin{tabular}{|c|c|c|c|c|c|}
\hline Yıllar & Toplam & Kamu & İşletmeler & Yükseköğrenim & Gönüllü kuruluşlar \\
\hline 1994 & 1106250 & 289424 & 759810 & 56818 & 198 \\
\hline 1995 & 1061044 & 282166 & 726568 & 52065 & 24 \\
\hline 1996 & 990743 & 270696 & 671061 & 48684 & 302 \\
\hline 1997 & 934637 & 266970 & 621584 & 45837 & 246 \\
\hline 1998 & 855190 & 255147 & 558547 & 41164 & 332 \\
\hline 1999 & 872363 & 258639 & 572624 & 40781 & 319 \\
\hline
\end{tabular}

Kaynak: Миндели, Л. Э. Чистякова, В. Е. (2016) Структура и Динамика Кадрового Потенциала Российской Науки, ИПРАН РАН, Москва, с. 12.

Tablo’da görüldüğü üzere araştırma kurumlarında çalışanların sayısı azalmıştır. Özellikle işletmelerin araştırma bölümünde çalışanların sayısı dikkat çekmektedir.

\section{Yeltsin Döneminde RF'de Türkiye Bilimi}

Yeltsin döneminde RF'de Türkiye bilimi hakkında fikir edinmek için Rusya Devlet Kütüphanesine kayıtlı tez özetleri 10 yıl öncesi ve 10 yıl sonrası karşılaştırılmıştır. Rusya Devlet Kütüphanesine kayıtlı açık erişim 1992-1999 yılları tez özetleri “Турции” ve “Турция” araması ile aynı sonucu, 25, vermiştir. Bir sonuç tekrar etmektedir (Кылычбейли, Элиф Хатун kaydı Элиф, Хатун Кылычбейли şeklinde tekrar etmektedir). Tezlerin 9'u iktisat, 7'i tarih ve kazıbilimi, 3’ü hukuk, kalanlar diğer alanlara dağılmıştır. 1999 yılına kayıtlı tez yoktur.

Ekran alındısı 3: 1992-1999 yılları için “Турции” sorgusu

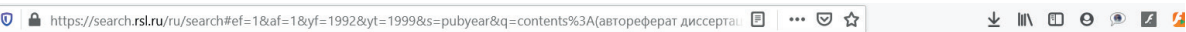

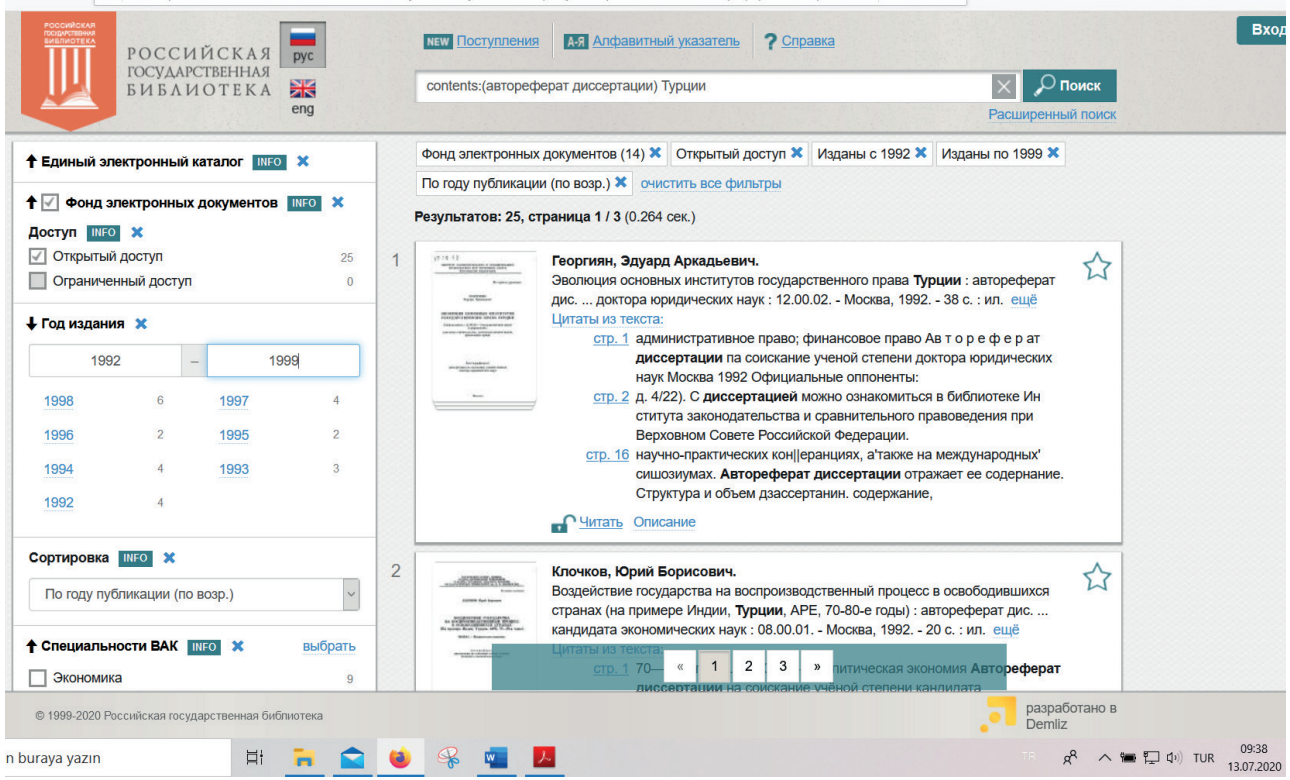


Yeltsin dönemini öncesi ve sonrası ile karşılaştırmak için sorgu tekrarlanmıştır. 1982-1991 arası aynı sorgu tekrarlanmış 6 tez özetine erişilmiştir. Tez özetlerinin 3'ü tarih ve kazıbilim, 2'si iktisat, 1'i hukuk alanına dairdir. 2000-2009 yılları için sorgu tekrarlanmış 106 tez özeti görüntülenmiştir. 177 tez özetinin 39'u tarih ve kazıbilim, 38'i dilbilim, 10'u siyaset bilimi, 7'si iktisat alanındadır.

1982-2009 yıllarına kayıtlı tezlerin coğrafi dağılımı farklılık arz etmekte iken hepsi Rusçadır. 1982-1991 yılları arasına kayıtlı tezlerin hepsi Moskova adresli iken 1992-1999 yıllarına kayıtlı tezler Moskova adresi ağırlıklı olsa da RF'nin şehirlerine ve eski SSCB cumhuriyetlerine dağılmaktadır. 2000-2009 yılları arası tezlerin RF şehirlerine dağılımı artmıştır.

Kayıtlara göre Yeltsin döneminde RF vatandaşlarının yanında Türkiye Cumhuriyeti kökenliler de RF'de Türkiye bilimine katkı sağlamaya başlamıştır. İlk katkı Şarkiyat enstitüsündendir. Şarkiyat Enstitüsünde Rusya Devlet Kütüphanesine kayıtlı ilk tezi Mehmet Toğaçar 1993'de tamamlamıştır. ${ }^{43}$ Tezin künyesi şu şekildedir: “Тогачар Мехмет. Социально-экономическая стратегия развития Турции: официальная и альтернативная концепции : автореферат дис. ... кандидата экономических наук : 08.00.29 / Ин-т востоковедения. - Москва, 1993. - 18 c." “Türkiye'nin Sosyo-ekonomik Gelişme Stratejisi: Resmi ve Gayriresmi Anlayış”.

Yeltsin döneminde RF'de ve Türk Cumhuriyetlerinde tez hazırlayan T.C. vatandaşları sayısı artmıştır. Mehmet Toğaçar'dan sonra Mikhail Söylemez'in 1995 'te Kazan'da, Zafer Çelik'in 1997'de Bişkek'te, Yunis Karaca'nın 1998'de Özbekistan'da, Elif Hatun Kılıçbeyli'nin Moskova' da tezini bitirdiği görülüyor. 2000-2009 yıllarında T.C. vatandaşlarının RF'de Türkiye bilimine katkısı artmıştır. İhsan Çomak, Mehmet Arslan (2003), Ömer Kocaman, Özlem Yılmaz, İlhan Kaçire, İlyas Üstünyer, Fatih Özbay, İsmet Biner (2004), Zeynel Ödemiş, Eyüp Bacanl, Nilay Ertürk (2005), Hülya Arslan, Mehmet Emin İkbal Dürre (2007), Bahar Güneş (2008), Yasin Tunç, Sinan Ogan (2009). 2000-2009 yıllarına kayıtlı 106 tez özetinin 16'sı T.C. vatandaşlarınca hazırlanmıştır. Yeltsin dönemi öncesinde Türkiye bilimine ilişkin çok az sayıda tez hazırlanırken Yeltsin dönemi sonrası Türkiye bilimine ilişkin hazırlanan tez sayısı artmıştır. Bir diğer fark Türkiye bilimine T.C. vatandaşlarının katkısı \% 15 'e ulaşmıştır. SSCB sonrası RF'de Türkiye Türklerini ve Türkiye'yi T.C. vatandaşlarından doğrudan öğrenme firsatı ortaya çıkmıştır.

RF'de Türkiye Cumhuriyeti vatandaşlarının Türkiye bilimine katkısı kamu kaynakları ya da özel imkânlar yoluyla olmuştur. RF döneminde kendi imkânları ya da ikili andlaşmalarla yüksek öğretim ya da araştırma için RF'ye gidenlerin sayısı zamanla artmıştır. SSCB döneminde akademik değişim (öğrenci ve personel) hemen hemen yokken 2 Kasım 1994’te Milli Eğitim Bakanlığı ile RF Yüksek Öğrenim Devlet Komitesi Arasında İşbirliği Anlaşması imzalanmıştır. 1996 yılından itibaren Rusya devlet yüksek öğrenim kuruluşlarında eğitim görmek üzere

43 Ли and Орешкова, Сектор Туриии Института Востоковедения РАН., 55. Mehmet Toğaçar'ı işyerinde ziyaretimde kendisinin Türkiye Cumhuriyetinden ilk tezi tamamlayan kişi olduğunu belirtmişti. Şarkiyat Enstitüsü Türkoloji biriminde görevli araştırmacıların kendisine maddi ve manevi destek olduğunu, onlara şükran borçlu olduğunu vurgulamıştı. Toğaçar zaman zaman Türkoloji birimini ziyaret ettiğini ifade etmişti. 
Türkiye’ye 15 kişilik burs kontenjanı verilmiştir. Yeltsin döneminde 1996-1997 yıllarından başlayarak Rusya Federasyonu tarafından Türkiye Cumhuriyeti Hükümeti emrine her yıl 5 araştırma bursu tahsis edilmiştir. Bursların hepsi kullanılamamıştır. Ben de şahsen Rusya Federasyonu Hükümetince 2003-2004 öğretim yılı için T.C. emrine verilen burslara müracaat edip asıl aday seçildim ancak yüksek lisans diplomam ve not döküm belgesi fotokopileri bulunmadığı gerekçesiyle RF makamlarınca kabul edilmediğim T.C. Milli Eğitim Bakanlığ D1ş İlişkiler Müdürlüğünün B.08.0.DİG.017.03.04.360.070.10/012034 sayı ve 28 Ekim 2003 tarihli yazısıyla bildirildi. Milli Eğitim Bakanlığında mülakat sırasında RF Eğitim Müşavirinin gayet düzgün Türkçe konuşması dikkatimi çekmiştir. Ankara Üniversitesi ile Moskova Devlet Üniversitesi (MDÜ) arasındaki andlaşma marifetiyle 2004-2005 yıllarında MDÜ Moskova Devlet Üniversitesi Asya ve Afrika Ülkeleri Enstitüsünde araştırma ve uygulamalarda bulundum. RF'de Türkiye bilimine T.C. vatandaşlarından katkısından başka RF' de tezlerini tamamlayan araştırmacılarından bir kısmı RF'de yaşamaya devam etmiştir. RF toplumuna Türkiye'yi doğrudan anlatma imkânı bulmuşlardır. Örneğin 2007'de tezini bitiren Mehmet Emin İkbal Dürre RF vatandaşlığgna geçmiştir, RF TV programlarında Kürtler ve Türkiye'ye ilişkin görüşlerine müracaat edilenlerin başlarında gelmektedir. RF'de Türkiye bilimine tezleriyle katkıda bulunanların bir kısmı Türkiye'ye dönmüş Türkiye'de Slav, Rus, Rusya’ya dair araştırmalarıyla Türkiye'de katkıda bulunmaktadırlar.

\section{SSCB Bilim Politikalarının ve Soğuk Savaşın Bilim Mirasının Yeltsin Dönemindeki Tesiri}

\section{SSCB Bilim Politikaları}

Öncelikle SSCB bilim politikalarının Türklük bilimine/Türkiyat'a/Türkoloji’ye tesirini anlamak gerekir. SSCB yöneticilerinde genelde, bilim ve sanat komünizmin kurulmasına hizmet etmelidir, önyargısı vardı. SSCB yöneticileri, sanatçıların ve akademisyenlerin hatta tabiplerin $^{44}$ sosyalist devlete, sosyalist topluma hizmet etmesi gerektiği önyargısıyla hareket edilmişlerdir. ${ }^{45} \mathrm{Bu}$ önyargı kısmen Yeltsin dönemine intikal etmiştir.

SSCB yöneticileri araştırmaları yönlendirilmiştir. Türklük bilimi/Türkiyat/Türkoloji ile Türkiye bilimi arasında fark vardır. SSCB dönemi yöneticileri SSCB'de araştırmacıları ideoloji, telkin ve propagandayla Türkiye bilimine yönlendirmişlerdir. Rusya İmparatorluğu

44 Cem Taylan Eren ve Tolga Binbay Sovyetler birliğinde “... "rejim muhalifi siyasi aktivistleri” sindirmek, zorla hastaneye yatırmak istemdışı tedaviyi uygulamak için kullanılmıştır. ...” iddiasının Batı'dan kaynaklı saldırgan propaganda olduğu yönündedir. “... Sovyet psikiyatrisinin özellikle birkaç kişi ya da kuruma dayanan örgütlü bir saldırı ile karşı karşıya kaldığı yönündedir.” Cem Taylan Erden and Tolga Binbay, "Sovyetler Birliği'nde Psikiyatri Kötüye Mi Kullanıldı?," Madde, Diyalektik ve Toplum, no. 1 (2008): 6-13.

45 SSCB yöneticilerince sanatın ve bilimin SSCB sistemine, devlete hizmetine dair çok sayıda yayın vardır. “... Sovyet rejiminin edebiyatı (ve genel olarak sanatı) rejim ideolojisine bir hizmet aracı haline getirmesi yeni sayılmaz. ... Sovyetler Birliği’nde yapılanların farkı, edebiyat daha sonra tüm sanat dallarının bir ideolojiye bağlanmasının kurumsallaştırılarak bir teori hâline getirilmesidir. ..." Tağızade, "Sosyalist Realizm: Kökeni, Oluşum Süreci ve Kavramı.”, 8. 
döneminde Vasilij Viladimiroviç Barthold'un eserleri Türklük bilimi eserleri iken Barthold'un ölümü sonrası araştırma alanı, metodu takip ettirilmemiştir. Barthold'un araştırma konularını, metodunu kullananlar engellenmiştir. Barthold Türklük bilgini/Türkiyatç//Türkolog iken SSCB dönemi Şarkiyat Enstitüsü Türkiye birimi mensuplarının geneli Türkiye bilginidir. ${ }^{46}$

Sovyet yönetimi Çarlık dönemi akademisyen ve yazarlarının pek çoğunu "burjuva aydını" diye nitelendirip, bu aydınlar ve eserleri dışlanmıştır. ${ }^{47}$ Rusya İmparatorluğunda Türklük araştırmaları, Türklük araştırmaları önde gelmekte iken SSCB'de Türkiye araştırmaları öne çıkarılmıştır. ${ }^{48}$

Sovyet yönetiminin ilk yıllarından itibaren Türklük araştırmalarından ziyade Türkiye bilimi çalışmalarının öne çıkarılıp Sovyet yönetiminin ihtiyaçlarına müzahir ilerlediği söylenebilir. Aynı durum Yeltsin döneminde de görülür. Yeltsin döneminin iktisadi sorunlarının çözümünde Türkiye tecrübesinden istifadeye yönelik, özellikle Türkiye'nin karma ekonomik modelden 24 Ocak 1980 sonrası dışa açık ve ihracata dayalı büyüme modeline geçişi tecrübesinden RF ekonomisi için faydalanmaya dönük araştırmalar dikkat çekicidir. ${ }^{49}$ RF'nin Türkiye araştırmacıları Türkiye'nin sosyoekonomik deneyimlerinden ders çıkarmanın Sovyet sonrası dönüşümde Rusya'ya faydalı fikirler sağlayabileceğini açıçca belirtmişlerdir. ${ }^{50}$

Yeltsin dönemi SSCB'nin Türklük ve Türkiye araştırmacılarını, araştırma kurumlarını kütüphanelerindeki kitaplarını, müzelerini, yazmalarını kısaca SSCB döneminin birikimini devraldı. Bundan dolayı Yeltsin döneminde Türklük araştırmalarını, Türkiye araştırmalarını ve araştırmacılarını anlayabilmek için bu devralınan mirasın genel niteliklerini anlamak gerekir. Öncelikle SSCB'de Türkiye biliminin öne çıkartılmasının bazı nedenleri vardır. SSCB'de milliyetler meselesinin SSCB'ye zarar vermemesine büyük dikkat gösterilmiştir. Belki bu dikkatte Stalin' in Milliyetler Halk Komiserliği tecrübesi de etkiliydi. Olası zarardan kaçınmak maksadıyla SSCB yöneticilerince genelde 1930'lu yıllardan itibaren olumlu ya da olumsuz şekillendirilen İslam, Türkiye ve Türkiye Türkleri akademik, bilimsel örtüye büründürülerek ya da okul kitaplarında SSCB toplumuna, öğrencilerine sunulmuştur. Bu politika sonuç vermiştir. SSCB'nin son yıllarında Türkler ve Türkiye ile ilgili algı şöyledir; "On yıl önce, bu genç Türklerle tanışmadan, ben Türkiye'yi hiç tanımıyordum. Geri kalmış bir çöl ülkesi, herkesin çarşaflı gezdiği, çok eşli yaşadığı bir yer zannediyordum. ...". ${ }^{51}$

46 Barthold sikkelerin tasnifi, tasviri, okunmasına katkıda bulunmuştur. Günümüzde Türkiye Sektörü mensupları kadim Türk dillerini, yazısını, yazıtlarını, sanatlarını, eserlerini, sikkelerini bilmezler, ilgilenmezler.

47 Çomak, "Vasili Dimitriyeviç Smirnov (1846-1922).", 283.

48 Leningrad Şubesi ağırlıklı olarak Eskiçağ ve Ortaçağ tarihiyle ilgilenirken Moskova Enstitüsü güncel sosyoekonomik meselelere, Türkiye bilimine, Türkiye’yi bilmeye yoğunlaşmıştır. Şahin Liaisan, "Geçmişten Bugüne Rusya'da Türkiye Araştırmaları.", 670.

49 Ulçenko, N. Y., Ekonomika Turtsii v usloviyah liberalizatsii (80-90-e godı) [Liberalleşme Şartlarında Türkiye Ekonomisi (1980'li-1990'lı Yıllar)], İsrail ve Yakın Doğu Araştırmaları Enstitüsü, Moskova 2002. Ve Urazova, Y. İ. (haz.), Turtsiya: novıye tendentsii ekonomiçeskogo razvitiya v 80-e godı [Türkiye: 1980'li Yıllarda Ekonomik Gelişmenin Yeni Eğilimleri], Nauka, Moskova 1991. ve Koptevskiy, V. N., Rossiya-Turtsiya: etap1 torgovo-ekonomiçeskogo sotrudniçestva [Rusya-Türkiye: Ticari ve

İktisadi İş Birliği Aşamaları], RBA Şarkiyat Enstitüsü Yayınları, Moskova 2003. dikkat çekicidir.

50 Şahin Liaisan, “Geçmişten Bugüne Rusya’da Türkiye Araştırmaları.”, 651.

51 T A Çistyakova, “Türkiye Sankt Peterburg’ta,” 664 Numaralı Rus-Türk Lisesi Beyaz Geceler Okul Gazetesi, $1998,1$. 
SSCB'de Türklük araştırmaları, eserleri, baskı sayısı azaltılmıştır. Türkleri, Türkiye'yi konu alan, Türkiye'ye yönelik araştırmalarda, her seviyedeki eğitimde, yayınlarda ideoloji, propaganda öne çıkmıştır. Örneğin İ. A. Fedesov’un “SSCB Tarihi” (1982) isimli kitabının "Rusya ve Balkan Halklarının Özgürlük Savaşı" isimli başlığı altında Fedesov Balkan isyanlarını sunumu dikkat çekicidir. Aslında belki bu sunum Fedesov'un özgür iradesine de bırakılmamıştır:

\begin{abstract}
“Rusya'nın mağlubiyeti Balkan halklarının Sultan baskısından kurtulmasını geciktirdi. Yunanların büyük bir kısmı, Moldovyalılar, Güney Slavlar, Bulgarlar, Boşnaklar, Hersekliler, kısmen Sırplar hala Türk esirliğinde idiler. Geri kalmış feodal Türkiye bu halkları ezerek ekonomik kalkınmalarını engelliyor, millî kültürü yok etmeye çalışıyordu. Balkan Devletleri özverili bir şekilde savaşıyorlardı fakat Türk baskısını kendi güçleri ile yenmeyi başaramıyorlardı. Onlar Rusya'ya müracaat ettiler. Rus halkı- devrimci demokratlar gerçekten Slav halklarını anlıyor ve onların baskıcılarla savaşına destek olarak tam özgürlüğe kavuşmaları için çabalıyorlardı.1875 yılında Bosna Hersek'te, 1876 Nisan'ında Bulgaristan'da isyan baş gösterdi. Türk cezalandırıcıları ateşle ve kılıçla bu isyanı durdurdular. Onlar köyleri ve şehirleri yaktılar. Acımasızca halkı öldürdüler ve kültürel anıtlarını yok ettiler. Sadece Bulgaristan'da Türk ordusu 30 binden fazla insanı kesti. Dehşetli cezalar dünya halklarının öfkesine ve kızgınlığına neden olmuştur." ${ }^{2}$
\end{abstract}

Milliyetlere mensubiyet yerine SSCB mensubiyet ve Sovyet insanın öne çıkarılması çabaları, Marksizm'in telkiniyle SSCB'yi oluşturan milletlerin Sovyet üst kimliğinde birleştirilmesi çabaları Türklük araştırmalarına engel olmuş, Türkiye araştırmalarını öne çıkarmıştır.

Marksizm-Leninizm'in kurucularının ve Sovyet devlet adamlarının Türkiye üzerine görüşlerine ilişkin L. Şahin'in tespitlerine göre 1917-1975 yılları arasında 573 yayın yapılmıştır. ${ }^{53}$ Her ne kadar Marksizmin önerdiği araştırma kalıbı, yöntemi Şarkiyat araştırmalarına katkı sağlasa da Li ve Oreşkova'nın tespitini atlamamak gerekir; “... Bilimimizi birçok yönden zenginleştirdi ve zenginleştirdi. ... Bu inkâr edilemez derecede olumlu. Ancak ideolojik at gözlükleri açıkça mevcuttu ve dahası, bilimimizin gelişmesine engel oldu. ${ }^{54} \mathrm{Li}$ ve Oreşkova doğru sorular sorulduğunu ancak sorulara nesnel yaklaşım, araştırma sorusuna farklı yaklaşım ve farklı araştırma yöntemleriyle cevap aranamadığını, yönetimce müsaade edilmediğini belirttiler. Li ve Oreşkova'ya göre Sovyet döneminde Şarkiyat araştırmaları F. Florovski'nin tabiri ile özetlenebilir; "Sorular doğru ancak cevaplar doğru değil." Li ve Oreşkova ayrıca yönetimin araştırmacılara güvenmediklerini, mümkün olduğunca Şarkiyat Enstitüsünde çalışmaya, bulunmaya zorladıklarını, aşırıya kaçan kontrol yöntemleri kullandıklarını belirttiler. ${ }^{55}$

52 Nigâr Maharramova Cengiz and Ahmet Şimşek, "Sovyetler Birliği Döneminde Rusya'da Okutulan Tarih Ders Kitaplarında Türk İmajı,” Cumhuriyet Tarihi Araştırmaları Dergisi, no. 26 (2017): 37-66, 57.

53 Şahin Liaisan, “Geçmişten Bugüne Rusya'da Türkiye Araştırmaları.”, 682.

54 Ли and Орешкова, Сектор Туричи Института Востоковедения РАН., 86-87.

55 Ли and Орешкова., 87. 


\section{Soğuk Savaşın Tesiri}

Soğuk Savaş SSCB’de Türkiye biliminin, Türklük biliminin önünde aşılamaz bir engel iken aynı zamanda Türkiye' de SSCB biliminin, SSCB'yi oluşturan Türklerin biliminin, bilgi almanın önüne aşılamaz bir engel olmuştur. Soğuk Savaşla Türkiye ve SSCB araştırmacılarının ortak çalışmaları, alan araştırmaları, doğrudan kaynaklara erişip özgün eserler vermelerinin önü kesilmiştir. Soğuk Savaşın Türkiye bilimine, Türklük bilimi önüne çıkardığı engeller, bıraktığı lekeler Yeltsin döneminde kısmen izale edilmiştir.

ABD ile SSCB rekabeti sanat ve sanatçılar arasında da yaşanmıştır. Sovyetlerde sosyalist realizmin öneminden, bu akıma uygun eserlerin yetersizliğinden bahseden onlarca kitap, yüzlerce makale yayımlanırken, Batı'da ise sosyalist realizmin yalanlar ve düzmeceler üzerine kurulduğu üzerine yayınlar kaleme alınmıştır. Yazarlar Birliği burjuvayla savaşan, komünist idealleri ön plana çıkaran, komünizme büyük bir tutku ve heyecanla bağlı olan karakterler hakkında yazılmasını istese de mümkün olduğunca yazarlar kendi istedikleri konularda, yetenekleri ve sansürün el verdiği ölçüde yazmaktaydılar. ${ }^{56}$

Türkiye'nin 1945 sonrası Batı'ya yönelmesi SSCB araştırmacılarının Türkiye kaynaklarına erişimini engellemiştir. Türklük ve Türkiye bilimi Türkiye’ye erişemeden yürütülmüştür. Soğuk Savaşla birlikte $\mathrm{SSCB}^{\rightarrow} \leftarrow$ Türkiye ilişkilerinin arasına ABD girmiştir. Soğuk Savaşın sonuna kadar ilişkiler genelde $\mathrm{SSCB}^{\rightarrow}{ }_{\leftarrow} \mathrm{ABD}^{\rightarrow} \stackrel{\leftarrow}{\leftarrow}$ Türkiye ilişkileri şeklinde yürütülmüştür. L. Şahin’in Türkiye'nin Batı bloğuna katılımının Türkiye bilimi ve Türkiye araştırmacılarına yansımasını şöyle değerlendirmiştir; “... Türkiye Batı Bloku'na katıldığı için Sovyet Turkologlar bu bilimsel açlığı en çok çeken uzmanlar arasında yerini almıştır. Gordlevskiy’nin 1947'de yakındığı üzere Türkoloji çalışmaları, Türkiye gerçeklerinden kopuk bir şekilde yürütülmüştür." ${ }^{57}$

SSCB yöneticileri 12 Mart 1947'de ABD Başkanı Truman mesajını Kongreye gönderince, SSCB radyo ve basını Türkiye' nin ABD kontrolüne girdiği yolunda bir kampanya başlatmıştır. ${ }^{58}$ 1950'li yıllarda yazılan Büyük Sovyet Ansiklopedisi'ne göre; “1948 yılında Türkiye ve ABD arasında yardım sağlanmasını öngören anlaşmanın imzalanması, Türkiye'nin fiilen egemenliğinin büyük bir kısmından vazgeçmesi anlamına gelmekteydi. Türkiye'de çok sayıda askeri üs kuruldu. Türk ordusu, filosu ve hava kuvvetleri Amerika'nın kontrolüne geçti. ..."59 Hakikaten 1950'li yıllarda Türkiye'de ABD nüfuzu olağan üstü artmış, DP iktidarından sonra AP de 'Küçük Amerika'ncı politikaları gönüllü ya da gönülsüz devam ettirmiştir. Türkiye' de ABD etkisiyle üniversiteler, makaleler, bilimsel görünümlü yayınlar, Kültür Bakanlı̆̆g, TRT vasitasıyla SSCB toplum ve devleti perdelenip, SSCB toplum ve devleti aleyhine toplumda önyargıya çabalanmıştır. ABD'de, Batı'da, Türkiye'de SSCB'nin sanatla, sinemayla, gazetelerle, kitaplarla karalanması Soğuk Savaş'ın başından sonuna kadar artan ya da azalan dozda devam

56 Gürsoy, Sovyet Dönemi Rus Edebiyatı (1953-1991)., 110.

57 Şahin Liaisan, "Geçmişten Bugüne Rusya’da Türkiye Araştırmaları.”, 673.

58 Ali Başaran, "Siyasi İlişsiler-Kültürel İlişkiler Etkileşimi: Türk-Rus İlişkileri Örneği,” Avrasya Etüdleri, no. 48 (2015): 101-42., 116.

59 Sharlak, "Büyük Sovyet Ansiklopedisi'nde Türkler.”, 138. 
etmiştir. ${ }^{60}$ Türkiye'de SSCB devleti ve toplumunu nesnel, tarafsız ${ }^{61}$ araştıran araştırmacı ve araştırma bulmak neredeyse imkânsızlaşmıştır. Araştırmacılar iki uçta, SSCB'ye aşk ya da SSCB'den nefret, toplanmıştır. Türkiye'de araştırmacılar komünistlikle yaftalanmamak için araştırma konularını seçerken ya da araştırmalarını yazarken kendi kendilerini sansürlemişlerdir. Sosyalizme gönül verenler, Türkiye'nin SSCB'nin izlediği ekonomik modeli takip etmesi gerektiğini savunanlar dışlanmış, itibarsızlaştırılmış, 1960 darbesi sonrası üniversitelerden atılanlar arsındadırlar. ${ }^{62}$ Soğuk Savaş yıllarında ABD tesiriyle düşman SSCB, İslam ve Türklük düşmanı, namussuz komünizm önyargısı eğitim kurumları, kitaplar, basın marifetiyle topluma yerleştirilmiştir. Kültür Bakanlığı kütüphaneleri raflarında propaganda amaçlı Sovyet toplum ve rejimi aleyhine kitaplara yer verilmiştir. Söz gelimi Beypazarı Halk kütüphanesinde John Barron'un KGB (Sovyet Gizli Casusluk Teşkilatının İç Yüzü Sovyetler Dünya Düzenini ve Dünya Devletlerini Yıkmak İçin Nasıl Çalışıyorlar) kitabı yer almaktadır. TRT’de ABD filmleri, TRT radyolarında ABD şarkılarına yer verilirken SSCB filmleri ve SSCB şarkıları hemen hemen hiç yayınlanmamıştır. ${ }^{63}$ Bir şekilde yayınlanan birkaç film nedeniyle tahkikat açılmıştır. Örneğin T.C. Kültür Bakanlığı'nın işbirliği ile 1934'te tamamlanan filmin 1969'da TRT'de gösterimi bile savcılığın, Başbakanın takibine konu olmuş, Meclise intikal ettirilmiştir. ${ }^{64}$ Bu örnek olay ABD'nin bu konuda ne kadar hassas olduğunu ve hangi seviyede olayı takip ettirdiğinin emaresi sayılabilir. TRT'de her gün ABD filmlerinin, şarkılarının yayınlanmasına karşılık SSCB kaynaklı eserlerin sansürlenmesinin kaynağı düşündürücüdür. Oysa Soğuk

60 "Batı sineması en klasik düşmanını yitirdi Elveda Komünizm!”, Milliyet gazetesi, 18 Ekim 1991, 14.

61 Tamamen, pür önyargısız tarafsız araştırmacının, Şarkiyatçının, Türkiyatçının olamayacağı aşikârdır. Önyargılı olmak bilimin tahrifi anlamına gelmemelidir. “““... Fakat, eğer, toplumun dışında duran soyut bir birey fikriyle iş görmeye kalkışırsak, ne geçmiş ne de bugün üstüne gerçek bir anlayışa varabiliriz." (Carr, 2013: 87).” Ali Başaran, Annales Araştırma Yöntemine Göre Türkiye'nin Uluslararası Politikadaki Yeri ve Rolünün Değişimine Rusya'nın Etkisi (1699-2017) (Ankara: İmaj Yayınevi, 2018)., 37.

62 Mehmet Ö. Alkan, “1960 Darbesi ve Üniversiteden Tasfiyeler: 147’ler Olay1,” Toplumsal Tarih, no. 286 (2017): 58-69. “ ... "Ahlâkî, ilmî ideolojisi yüzünden yüz kızartıcı notlara sahip olan, bilhassa çoğu komünist, mason, kifayetsiz, cinsî sapık, Kürt devleti kurmak isteyen, asistanlarını metres olarak kullanan, doçentin yazdığı kitaba imzasını koyan, senede 3-5 kere fakülteye uğrayan üyeleri affettik”, 62.

63 “... Film tüm dünya ülkelerinde özgün adının tam çevirisi olan "Moskova Gözyaşlarına İnanmıyor” anlamına gelen adlarla gösterilirken, Türkiye'de hem sinemalarda (1987) hem de televizyonda (1989) gösterilirken "Moskova” sözcüğü yerine “Aşk” sözcüğü getirilerek “Aşk Gözyaşlarına İnanmıyor” adı tercih edilmiştir. Bu adlandırmada, henüz Soğuk Savaş döneminin sona ermediği bir tarihte, karşı bloğun simgelerinden olan bir sözcüğün bilerek ayıklanması amacı güdülmüş olabileceği ..." https://tr.wikipedia.org/wiki/A\%C5\%9Fk_G\% C3\%B6zya\%C5\%9Flar\%C4\%B1na_\%C4\%B0nanm\%C4\%B1yor Erişim 01 Ağustos 2020.

64 Varlık Özmenek, o gece yaşadıklarını şöyle anlattı:

"Filmi bilen ve bulan kişi benim. Sovyet Büyükelçiliği’nden istedik. Filmin orijinalini bulup bize getirdiler. Film gösterildiği sırada yayın odasındaydık. Filmin ortalarına doğru Öztrak stüdyoya geldi ve 'Bu film ancak Moskova'da seyrettirilebilir. Yayını kesin’ diyerek yayını durdurdu. Bu olay galiba dünya televizyon yayıncılık tarihinde de bir ilk oldu. Öztrak geldiği zaman ben anladım ki filmi bilmiyor. Öbür gün yer yerinden oynadı ve savcılık hareket geçti. Diğer gün de TRT Yönetim Kurulu toplandı. Öngören'in görevine son verilirken, bana disiplin cezası verildi. Savcılık ise daha sonra takipsizlik verdi." https://www.milliyet.com.tr/gundem/yasaklibelgesel-kosk-un-sitesinde-982318 Erişim 01 Ağustos 2020. “Türkiye'nin Kalbi” filmi için bkz. https://vimeo. com/358652907/52c236e57b Erişim 01 Ağustos 2020. 
Savaş öncesi II. Dünya Savaşı sırasında aktif tarafsızlık politikası gereğince ABD filmlerinin Türkiye'ye girişi, seyirciyle buluşması engellenebiliyordu. ${ }^{65}$

Gazete kupürü 1: TRT yayını

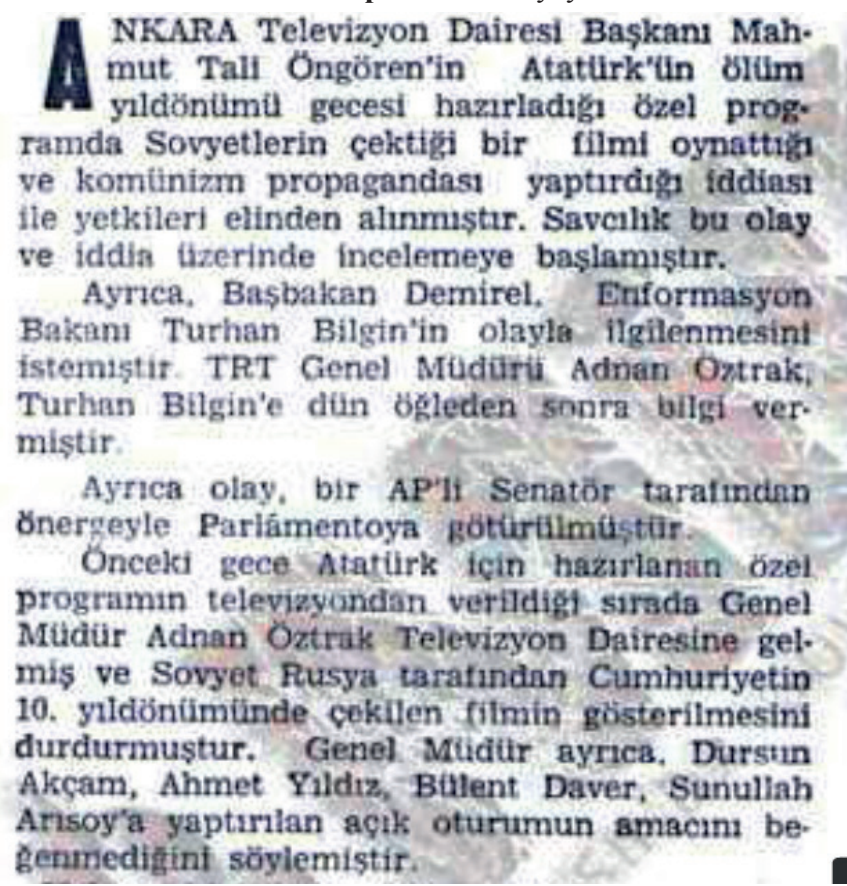

Kaynak: Milliyet gazetesi, 12 Kasım 1969, 1.

SSCB'nin 1945'teki talepleriyle birlikte aktif ABD taraflılığı dönemine girilmiş ancak sonra istense de çıkılamamıştır. ABD'ye, ABD askerlerine, ABD 6'ncı filosunun ziyaretlerine 1960'lı yıllarda tepki daha da artmış, Anadolu'nun işgaline ABD’nin yardımı hatırlatılmıştır. “... Yunanlılar İzmir’e çıkarken onları getirip karaya çıkışlarında destekleyen, ... zırhlılar arasında Amerikan 'Arizona' destroyeri de vardı”. ${ }^{66 ~ “ . . . ~ B a s ̧ k a n l a r ı, ~ A m e r i k a ’ n ı n ~ s ı n ı r l a r ı ~}$ Kars’tan başlar diyor. Dost diye içimize girdi, sinsi sinsi bizi soyuyor? Vatandaş..." "67 Türkiye'de ABD karşıtları SSCB taraftarı göründükleri için SSCB'nin 1945'teki talepleri ve SSCB'nin de din, İslam karşıtı uygulamalarından ABD istifade ettiği, propagandasını yaptığı için başarılı olamamışlardır.

65 Efe Sıvış, “Uluslararası İlişkiler Disiplininde Propaganda: Sinema Filmlerinin Dış Politikada Kullanımı; 1940’lı Yıllarda Türkiye Örneği," in II.ALKÜSAM Uluslararası İlişkiler Kongresi, ed. Tolga Öztürk and Eren İrfanoğlu (Alanya: Alanya Alaaddin Keykubat Universitesi, 2019), 27.

66 Türkkaya Ataöv, “'Bu Sevinç Neden?,”” Forum, 1968.

67 Feryat Bulut, “68 Kuşağı Düşünce Yapısında Atatürk ve Atatürkçülük” (T.C. Dokuz Eylül Üniversitesi Atatürk İlkeleri ve İnkılâp Tarihi Enstitüsü, 2009)., 150. 
Türk ve Sovyet toplumlarının doğrudan temaslarına müsaade edilmeyip yöneticilerce yürütülen telkin, propaganda araçlarından özellikle sinema ve televizyon yayınlarında karşı taraf tarif ve tasvir edilmiştir. Sinema zaten SSCB içinde rejim lehine maharetle kullanılıyordu. SSCB yöneticileri devrimden hemen sonra sosyalist ideolojinin kitlelere aktarılmasında ve meşrulaştırılmasında filmlerin etkin rolünü anlayınca SSCB sinemasına ideolojik bir meşruiyet aracı niteliği kazandırmışlardır. ${ }^{68}$

Üniversitelerin, araştırmacıların doğrudan birebir temasları engellenmiştir. SSCB, SSCB'de yaşam ve SSCB'de yaşayan toplumlar, SSCB bilim ve sanatı hakkında Türkiye'ye Batı'dan, ABD'den, Batı üniversitelerinden ithal bilgi, araştırma ve fikirler sokulmuştur. Türkiye'de İngilizce kaynak kullanan araştırmacı ve öğretim üyeleri hızla artarken Rusça kaynakları kullananlar artmamış, kullananlar da zamanla vefat etmiştir. Akdes Nimet Kurat, Ahmet Zeki Velidi Togan' $1 n^{69}$ vd.'nin yeri doldurulamamıştır. Bu halde Rusya hakkında Rusça kaynaklardan asıl araştırmalar yerine genelde Batı araştırmacılarından, İngilizceden çeviriler, derlemeler ile SSCB anlaşılmaya, anlatılmaya çabalanmıştır. Yasemin Gürsoy Şumnulu, Trofim Lısenko hakkında Türkçe yazılanların kaynakçalarını incelediğinde Rusça kaynakların kullanılmadığını tespit etmiştir. Lısenko'yu savunan yazılar da yeren yazılar da tetkik edildiğinde, değerlendirildiğinde Türkiye'de araştırmacıların genelde tarafsız değil ya Batı ya da SSCB tarafını seçtiğini göstermektedir. SSCB araştırmacıları Türkiye'deki Türklük araştırmacılarını Türkçü-Turancı olarak değerlendirmesi araştırmacılar ve araştırmaların önünde ayrı bir engel olarak kalmıştır.

Türk ve Sovyet toplumlarının doğrudan temasları olmadığı için halk siyasi iradenin telkin ettiği şekilde karşı tarafı algılamıştır. 1980'li yıllarda toplumların karşılıklı algılayışlarını Hakan Aksay şöyle özetlemiştir: “Eylül 1981'de Sovyetler Birliği'nde öğrenime başladığım sıralarda ortalıkta pek Türk yoktu. Sınıf arkadaşlarım Türkiye'nin haritadaki yerini bilmezdi. Daha yaşlı olanlar, “ABD’nin sadık müttefiki” dedikleri Türkiye'den geldiğim için benimle konuşurken ihtiyatlı davranırlardı. Komşu olmamıza karşın bilinmez ve uzak ülkelere özgü silik bir izlenimimiz vardı. "Aa, hiç Türk görmemiştim” cümlesini çok sık duyardım.”70

\section{Yeltsin Döneminde Şarkiyat Enstitüsü Türkiye Birimi}

SSCB sonrası Yeltsin döneminde Şarkiyat Enstitüsü Türkiye biriminin araştırmacıları, araştırma öncelikleri, işlevi büyük ölçüde aynı kalmıştır. Yeltsin döneminde Şarkiyat Enstitüsü mensupları 1956'da Türkiye biriminin kuruluşundan günümüze SSCB ve RF'de Türk

68 Mustafa Ali Minarlı and Burak Yılmaz, “Asya Politik Sineması Üzerine Notlar,” İnsan ve Ínsan Dergisi, no. 3 (2015): 37-50.

69 Türkiye'de Türklük araştırmacıları bazen de Türkçü, Turancı olarak yaftalanmıştır. Togan Turancılık davasından 10 yıl hapse mahkûm edilmiştir.

70 Hakan Aksay, “Türk İmajı: Dün, Bugün... Yarın?,” Avrasya İşbirliği Perspektif, no. 3-4 (1997): 3. Gerçeğin görmezden gelinmesi günümüzde de kimi ülke yöneticilerince sürdürülmektedir. “... Jeanne Cavelier yaptı̆̆ açıklamada; Türkmenistan yönetiminin, devlet basın-yayın organlarına 'koronavirüs' terimini kullanma yasağı getirdiğini söyledi. Cavelier, Türkmenistan yönetiminin böylelikle ülkedeki salgın konusundaki gerçekleri saklamaya çalıştı̆̆ını savundu." https://www.yenisafak.com/koronavirus/turkmenistanda-koronavirus-demekartik-yasak-3532434 Erişim 28 Temmuz 2020. 
kökenlilerin sayısı çok yüksek olduğu halde Moskova'daki Şarkiyat Enstitüsünün Türkoloji birimi çalışanları arasında Türk kökenlilere ya görev verilmemiş ya da az sayıda Türk kökenliye görev verilmiştir. Günümüzde Şarkiyat enstitüsünün "Yakın ve Orta Doğu Ülkeleri Tetkikleri Merkezi” altındaki Türkiye Sektörü’ne mensup Türk kökenli yoktur. Halbuki Türk kökenlilerin Türkiye Türkçesi ve diğer Türkçe lehçelerine yakınlığı bir kazanç olarak görülüp, Türklük araştırmalarının güçlendirilmesine kaynaklık edebilirlerdi. Neden görev verilmediğinin açıklığa kavuşmasında fayda vardır. Belki bunun kökeni SSCB'nin milliyetler politikasına gitmektedir. ${ }^{71}$ Türkiye biriminin Stalin'in ölümü/öldürülmesi sonrası 1956'da kurulması tesadüfi değildir. SSCB'de devletten, siyasetten bağımsız bilim, bilim kurumları olmadığından Türklük bilimi de SSCB yöneticilerinin artan ya da azalan etkisinde seyretmişti. ${ }^{72}$ Şarkiyat Enstitüsünün işlevine gelince, SSCB doğusunun şekillendirilmesi, yönlendirilmesi, yönetilmesinin bir arac1 olup olmadığı hakkında şüpheler süregelmiştir. ${ }^{73}$ Bir diğer işlevi Komünist Parti ve devlet yöneticilerine bilgi temini KGB ajanı Yevgeni Maksimoviç Primakov'un yönetiminde (19771985) belirginleşmiştir. ${ }^{74}$

Yeltsin döneminde araştırmacılar SSCB dönemine nispeten daha özgür olsalar da RF yönetimi araştırma kurumlarını yönlendirmeye devam etmiştir. Aslında araştırma, öğretim özgürlüğü sınırı ya da sınırsızlığı muğlaktır. Tarihi verilere baktığımızda, genelde şarkiyat araştırmaları ve kurumların oluşumu Rusya İmparatorluğunun ihtiyaçlarına karşılık geliyordu. Şarkiyat araştırmalarının kaynağı devlet ihtiyaçları olurken, devlet şarkiyat araştırmalarının maliyetlerini karşılarken şarkiyatçıların sınırsız özgürlüğünün en başından olmayacağı öngörülebilir. Devletin ihtiyaçları haricinde şarkiyatçılar birbirlerinin özgürlüklerini kraldan çok kralcı olarak da kısıtlamışlardır. Örneğin Smirnov Petersburg'da "Müslüman işleri” ile ilgili sansür dairesinin yöneticiliğini yapıyordu. Smirnov belki kendiliğinden, Osmanlı devletinin milli birliğinden uzaklaşmasının yıkıcı etkiler doğurduğunu tespitinden, kaynaklı Rusya İmparatorluğu içindeki Türk köklü toplumların Ruslaştırılmasını misyon edinmiştir. ${ }^{75}$ SSCB döneminde Türk köklü toplumlar Sovyet Ruslarına benzetilmeye çabalanmış, Kazakistan'da epeyce başarı sağlanmıştır. Simirnov'un Ruslaştırılma politikası Smirnov'u nesnellikten, tarafsızlıktan uzaklaştırmıştır. Gordlevski, Smirnov'un aşırı Rus milliyetçisi olduğunu yazar. ${ }^{76}$ Şüphesiz her bir araştırmacı bir ülkeye, millete mensup olacaktır ancak milliyetini Şarkiyatçı ya da Türklük araştırmacısı hüviyetinin önüne geçirmesi halinde bilime değil propagandaya yöneldiği söylenebilir. Aynı şekilde araştırma kurumları da bir devlete, ülkeye ait olabilir. Ancak bilim kurumu niteliğinin geride kalması halinde itibarsızlaşacaktır. RF döneminde de Şarkiyat ve Türkiye bilimi yöneticilerin peşi sıra sürüklenme riskiyle karşılaşmıştır. Şarkiyat Enstitüsünün RF tarafından dış politika aracı olarak kullanılmasının bir örneği Kürt konferansıdır. Şubat 1994'ün sonunda

71 Stalin dönemi milliyet politikaları için bkz. Özel, "Stalin Dönemi Rus Milliyetçiliği ve Politikaları."

72 Kemper, "Introduction Integrating Soviet Oriental Studies.", 8.

73 Kemper., 5.

74 Kemper., 16.

75 Çomak, "Vasili Dimitriyeviç Smirnov (1846-1922).", 283.

76 https://islamansiklopedisi.org.tr/smirnov-vasily-dmitrievic Erişim 15 Ağustos 2020. 
Moskova' da Kürt konferansı düzenlenmiştir. Konferans PKK, BDT Kürtleri Derneği, Şarkiyat Enstitüsü vd. kuruluşlarca düzenlenmiştir. T.C. Dış İşleri Bakanlığı Kürt konferansını RF Dışişleri Bakanlığı nezdinde protesto etmiştir. ${ }^{77} \mathrm{SSCB}$ döneminde Şarkiyatçılar Komünist Partisi çizgisinden ayrılmasına müsaade edilmediğine benzer şekilde Putin döneminde "Yeni Çar-новый царь” Putin' in kurduğu rejime (yasaların diktatörlüğ $\ddot{̆}^{78}$ ) aykırı araştırma ve yayın yok gibidir.

SSCB sonrası Şarkiyat Enstitüsü Türkiye biriminin araştırmacıları, araştırma öncelikleri, işlevi büyük ölçüde aynı kalsa da SSCB mirasının tesiri sürse de değişim yönünde görüşler ifade edilmiştir. L. Şahin'e göre Sovyet sonrası dönemde RF'de Türkiye araştırmacıları, "ezelî düşmanlık” veya "güneye doğru ilerlemenin Rusya'nın kaderi olduğunu” savunan yaklaşımın artık eskimiş olduğunu söylemeye başlamışlardır. Rusya-Osmanlı ilişkileri tarihinin yeniden gözden geçirilmesi, siyasi ve ideolojik saptırmalardan kurtarılması gereği ifade edilmiştir. Türkiye araştırmacıları, Osmanlı Devleti tarihini, birçok ulusu ve birçok dini barındıran ve "Rusya ile eşzamanlı olarak ve bir anlamda da benzer şekilde gelişen" bir devletin tarihi olarak araştırılması gerektiğine işaret etmişlerdir. ${ }^{79}$

Günümüzde “Türkiye Sektörü” Rusya Bilimler Akademisi Şarkiyat Enstitüsünün Yakın ve Orta Doğu Ülkeleri Tetkikleri Merkezi/Центр изучения стран Ближнего и Среднего Востока, (2010 yılına kadar Türkiye bölümünde) altında yer almaktadır. ${ }^{80}$ Günümüzde bu merkez 4 ülke ve bir meseleyi (Kürt) tetkik etmekle görevlidir. Afganistan, İran, Kürt Tetkikleri ve Bölgesel Sorunlar, Pakistan, Türkiye. Yeltsin döneminde Türkiye sektörünün başkanlığını Kireev ve Ulçenko yapmıştır.

Abdulla Mardanovich’ten sonra Türkiye birimi başkanı V. I. Danilov daha sonra N. G. Kireev oldu. Kireev, Yeltsin dönemi de dahil 1985-1999 yılları arasında Türkiye Sektörünün başındayd1. 1999'da başkanlığa N. Y. Ulçenko aday gösterildi. Aday gösterildiğinde en genç Türkiye Sektörü mensubuydu. Ulçunko'nun seçildiği sırada kurum dağılma görüntüsünü veriyordu. Türkiye Sektörü mensuplarının çoğu emeklilik yaşındaydı. Yeltsin döneminde Türkiye Sektörünün genç mensupları ve lisansüstü öğrencileri ayrılmıştı çünkü maaşlar asgari geçim haddinden bile düşüktü. Türkiye Sektörü mensupları 2-3 ay başka üniversitelerde hatta ortaöğretim kurumlarında da çalışmıştır. Ulçenko Türkiye Sektörü başkanlığı haricinde Moskova Devlet Üniversitesi Asya ve Afrika Ülkeleri Enstitüsü’nde, Rusya Devlet Beşeri Bilimler Üniversitesi'nde ve Uygulamalı Doğu Çalışmaları Enstitüsü’nde Türkiye ekonomisi ve iktisadi coğrafyası dersleri vermiştir. Türkiye Sektörü Ulçenko'nun seçimi sonrası nitelikli mezunlar vermiş ve Yeltsin döneminin buhranlarını atlatmış görünüyordu. Yeltsin döneminde Türkoloji Sektörü mensuplarının yayınlarının sayısı çok düşükken 2000 sonrası epeyce arttığ

77 Aleksey Cickin, "Kürtler, Bağımsız Devletler Topluluğu Da Dahil Olmak Üzere Self-Determinasyon İstiyorlar," Megapolss Express, March 2, 1994.

78 “... "İktidarım döneminde Rusya’da şahısların değil, yasaların diktatörlüğü olacak” ...” https://www.hurriyet. com.tr/dunya/siz-beni-sayiyor-musunuz-7727965 Erişim 20 Temmuz 2020.

79 Şahin Liaisan, "Geçmişten Bugüne Rusya'da Türkiye Araştırmaları.”, 648-649.

80 https://bsv.ivran.ru/center Erişim 18 Ağustos 2020. 
görülmüştür. ${ }^{81}$ Türkiye Sektörü mensuplarından büyük ölçüde Türklük bilimine değil Türkiye bilimine katkı beklenmektedir. Yeltsin ve Putin dönemlerinde de Türklük araştırmalarından ziyade Türkiye bilimi araştırmaları ve yayınları süregitmektedir. Şarkiyat Enstitüsü Türkoloji Sektörünün SSCB yöneticilerinin taassubundan Yeltsin döneminde kurtulsa da pür bilim yolunda ya da başka bir deyişle Edward Said'in şarkiyatçılığa yönelttiği tenkitlerden ari değildir.

Türkiye sektörü mensupları sayısı zamanla artış azalış gösermiştir. Yeltsin döneminde azalmıştır. Türkiye Sektörü'den çalışıp Yeltsin döneminde hayatta olanlar E. İ. Urazova, N. G. Kireev (1985-1999 arası başkandı), C. F. Oreşkova, H. Y. Ulçenko (1999'dan günümüze başkandır), B. M. Potskhveriya, V. I. Danilov (1976-1985 arası başkandı), R. P. Kornienko, A. K. Sverchevskaya, Y. A. Li, A. P. Baziyants, G. I. Starchenkov.

Yetsin ve Putin dönemlerinde Türkiye Cumhuriyeti'nin bilimsel kuruluşlarıyla Sovyet döneminde hiç olmadığı kadar yakın ilişkiler kurulmuştur. Türkiye sektörü Rus/Rusya-Türkiye İşadamları Birliğince desteklenmiştir. Türkiye Cumhuriyeti’nin Moskova Büyükelçiliği faaliyetlerine ilgi göstermiştir. Türk Tarih Kurumu ile ilişkiler arttırılmıştır.

\section{Sonuç ve Öneriler}

Rusya İmparatorluğunda Alman kökenli araştırmacıların öncülüğünde şarkiyat araştırmaları müesseseye kavuşturulmuş ve yine Alman kökenli araştırmacıların öncülüğünde ilerleme kaydetmiştir. Rusya İmparatorluğu sonrası SSCB'de imparatorluktan miras kalan tüm kurumlara, araştırmacılara ve tabii ki şarkiyat kurumlarına ve şarkiyatçılara yeniden şekil verilmeye çabalanmıştır. Sanat ve bilime komünist topluma erişme yolunda görev tanımlandığından şarkiyat araştırmaları, Türklük araştırmaları da bu misyondan etkilenmiştir. SSCB yöneticileri özgür, pür bilim yolunda ilerlemekten araştırmacıları alıkoymuştur. SSCB sonrası Yeltsin döneminde yaşanan keşmekeş, kıtlık, yokluklar Şarkiyat Enstitüsüne, Türkiye Sektörüne de yansımıştır. Araştırmacılar yoksulluk sınırı altındaki maaşlarını dahi vaktinde alamamıştır. Türkiye Sektörüne mensup gençler ayrılmış mutat faaliyetler dahi yürütülememiştir. Şarkiyat araştırmacıları hayatlarını idame ettirmek için başka kurumlarda da çalışmak zorunda kalmıştır. Yeltsin döneminde Türkiye Sektörü mensuplarının araştırma, yayın sayısı azalmıştır. Yeltsin dönemi sonundan itibaren kısmen iyileşme görülmüştür.

Yeltsin döneminin olumlu tarafı araştırmacılar üzerinde yönetimin tahakkümü azalmıştır. Araştırmacılar kısmen özgürleşmişlerdir. Ancak SSCB mirası, önyargılar tamamen izale edilememiştir. Şarkiyat Enstitüsü PKK ile birlikte konferans düzenlese de Türkiye-RF ilişkilerine ilişkin olumlu katkılar sunmuştur. Yeltsin döneminin iktisadi buhranı Türkiye Sektörü mensuplarının Türkiye'de piyasa ekonomisine geçiş tecrübesine ilgilerini arttırmıştır.

Bundan sonraki araştırmalarda Yeltsin döneminde bilim Türkiye Sektörünün yapısı, mensupları, diğer sektörler ve diğer Türkiye bilimi kurumlarıyla ilişkileri tetkik edilebilir. SSCB'den bağımsızlaşan cumhuriyetler ile Türkiye'nin ilişkilerinin artışına Türkiye Sektörü

81 Liaisan Şahin, “Rusya'da Türkiye Üzerine Yayımlanan Monografilerin Listesi (1991-2016)," Marmara Türkiyat Araştırmaları Dergisi 3, no. 2 (2016): 281-85. 
mensuplarının değerlendirmeleri tespit edilebilir. SSCB sonrası Türkiye'de Turancılığın coşkusuna dair şüphelerin izleri Türkiye sektöründe aranabilir. Sektörünün ve Türkiye mensuplarının Türkiye’ye ilişkin eserleri, eserlerinde olumlu ya da olumsuz yaklaşımları değerlendirilebilir. Türkiye Sektörünün Yeltsin dönemi ile Putin dönemi karşılaştırılabilir.

Hakem Değerlendirmesi: Dış bağımsız.

Çıkar Çatışması: Yazar çıkar çatışması bildirmemiştir.

Finansal Destek: Yazar bu çalışma için finansal destek almadığını beyan etmiştir.

Peer-review: Externally peer-reviewed.

Conflict of Interest: The author has no conflict of interest to declare.

Grant Support: The author declared that this study has received no financial support.

\section{Kaynakça/References}

Aksay, Hakan. “Türk İmajı: Dün, Bugün... Yarın?” Avrasya İşbirliği Perspektif, no. 3-4 (1997): 3.

Aleksey Cickin. "Kürtler, Bağımsız Devletler Topluluğu Da Dahil Olmak Üzere Self-Determinasyon İstiyorlar." Megapolss Express, March 2, 1994.

Alkan, Mehmet Ö. “1960 Darbesi ve Üniversiteden Tasfiyeler: 147’ler Olay1.” Toplumsal Tarih, no. 286 (2017): 58-69.

Başaran, Ali. Annales Araştırma Yöntemine Göre Türkiye’nin Uluslararası Politikadaki Yeri ve Rolünün Değişimine Rusya'nın Etkisi (1699-2017). Ankara: İmaj Yayınevi, 2018.

__. "Siyasi İlişkiler-Kültürel İlişkiler Etkileşimi: Türk-Rus İlişkileri Örneği.” Avrasya Etüdleri, no. 48 (2015): 101-42.

Bulut, Yücel. “Oryantalizmin Ardından.” Sosyoloji Dergisi 3, no. 24 (2012): 1-57.

. "Sunuş." Sosyoloji Dergisi 3, no. 24 (2012): 7-20.

Çistyakova, T A. "Türkiye Sankt Peterburg’ta.” 664 Numaralı Rus-Türk Lisesi Beyaz Geceler Okul Gazetesi. 1998.

Çomak, İhsan. "Vasili Dimitriyeviç Smirnov (1846-1922)." Uluslararası Sosyal Araştırmalar Dergisi 5, no. 21 (2012): 278-84.

Erden, Cem Taylan, and Tolga Binbay. "Sovyetler Birliği’nde Psikiyatri Kötüye Mi Kullanıldı?” Madde, Diyalektik ve Toplum, no. 1 (2008): 6-13.

Feryat Bulut. “68 Kuşağı Düşünce Yapısında Atatürk ve Atatürkçülük.” T.C. Dokuz Eylül Üniversitesi Atatürk İlkeleri ve İnkılâp Tarihi Enstitüsü, 2009.

Fortescue, Stephen. "The Russian Academy of Sciences and the Soviet Academy of Sciences: Continuity or Disjunction?” Minerva, no. 30 (1992): 459-78.

Gürsoy Şumnulu, Yasemin. “Türk Kaynaklarında Trofim Lisenko.” In Процеси Украӥнського Державотворення Від Давніх Часів До Сьогодення (з Нагоди 1000-Річчя з Початку Правління Ярослава Мудрого) 18 Квітня 2019 Року, 66-69. Ternopil, 2019.

Gürsoy, Yasemin. Sovyet Dönemi Rus Edebiyatı (1953-1991). İksad, 2018.

Henri Alleg. Büyük Geri Sıçrama Ylkıntı ve Umut Rusyasonda Röportaj. 2nd ed. İstanbul: Evrensel Basım Yayın, 2013. 
Kemper, Michale. "Introduction Integrating Soviet Oriental Studies." In The Heritage of Soviet Oriental Studies, edited by Michale Kemper and Stephan Conermann, 1-25, n.d.

Maharramova Cengiz, Nigâr, and Ahmet Şimşek. "Sovyetler Birliği Döneminde Rusya'da Okutulan Tarih Ders Kitaplarında Türk İmajı.” Cumhuriyet Tarihi Araştırmaları Dergisi, no. 26 (2017): 37-66.

Minarlı, Mustafa Ali, and Burak Yılmaz. "Asya Politik Sineması Üzerine Notlar.” İnsan ve İnsan Dergisi, no. 3 (2015): 37-50.

Mustafa Özbaş. "Rus Şarkiyat Çalışmalarının Temelleri Rus Tarihinin Başlangıcından 15. Yüzyıla Kadar." Türk Dünyası İncelemeleri Dergisi 9, no. 2 (2009): 147-53.

Özel, Merve Suna. "Stalin Dönemi Rus Milliyetçiliği ve Politikaları.” Kırıkkale Üniversitesi Sosyal Bilimler Dergisi 4, no. 2 (2014): 99-122.

Perera, Judith. "Russia's Scientists Take to the Streets." NewScientist, 1996. https://www.newscientist.com/ article/mg15220521-300-russias-scientists-take-to-the-streets/.

Perera, Judith, and Andrei Ivanov. "RUSSIA-SCIENCE: An End to Science?," 1996. http://www.ipsnews. net/1996/03/russia-science-an-end-to-science/.

Şahin Liaisan. “Geçmişten Bugüne Rusya'da Türkiye Araştırmaları.” Türkiye Araştırmaları Literatür Dergisi 8, no. 15 (2010): 645-96.

Şahin, Liaisan. "Rusya'da Türkiye Üzerine Yayımlanan Monografilerin Listesi (1991-2016).” Marmara Türkiyat Araştırmaları Dergisi 3, no. 2 (2016): 281-85.

Said, Edward W. Orientalism. 1st ed. London and Henley: Routledge \& Kegan Paul Ltd., 1978.

Sharlak, Yevgeniya. "Büyük Sovyet Ansiklopedisi’nde Türkler.” T.C. Ankara Üniversitesi Sosyal Bilimler Enstitüsü Tarih Bölümü (Genel Türk Tarihi) Anabilim Dalı, 2017.

Sıvış, Efe. "Uluslararası İlişkiler Disiplininde Propaganda: Sinema Filmlerinin Dış Politikada Kullanımı; 1940'lı Yıllarda Türkiye Örneği.” In II.ALKÜSAM Uluslararası IIlişkiler Kongresi, edited by Tolga Öztürk and Eren İrfanoğlu, 27. Alanya: Alanya Alaaddin Keykubat Universitesi, 2019.

Tağızade, Leyla. "Sosyalist Realizm: Kökeni, Oluşum Süreci ve Kavramı." Modern Türklük Araştırmaları Dergisi 3, no. 4 (2006): 7-24.

Türkkaya Ataöv. “"Bu Sevinç Neden?” Forum, 1968.

Turyalay, Svetlana. "Türkiye Az Kalsın Sovyetlere Nasıl Dahil Oluyordu. Eski KGB Elemanlarının İfadeleri." Komsomolskaya Pravda. July 26, 1995.

А.Г. Аллахвердян, Н.С. Агамова. "Российская Наука в Постсоветский Период: От Кадрового Обвала к Численной Стабилизации.” Наука Та Наукознавство, по. 1 (2005): 51-62.

Кононов А. Н. “Тюркология // Азиатский Музей.” In Ленинградское Отделение Института Востоковедения АН СССР, 400-427, 1972.

Ли, Ю. А., and С. Ф. Орешкова. Сектор Туриии Института Востоковедения РАН. Москва: Институт востоковедения РАН, 2009.

Миндели, Л. Э., and В. Е. Чистякова. Структура и Динамика Кадрового Потенциала Российской Науки. Москва: ИПРАН РАН, 2016.

http://stat.edu.ru/scr/db.cgi?act=listDB\&t=2_6_1a\&ttype=2\&Field=All Erişim 18 Ağustos 2020.

http://vivovoco.astronet.ru/VV/PAPERS/ECCE/VIETSOLJ.HTM Erişim 07 Ağustos 2020. 
http://www.daokedao.ru/2014/08/18/institut-prakticheskogo-vostokovedeniya-lishen-litsenzii/ Erişim 10 Ağustos 2020

http://www.kremlin.ru/acts/bank/9204 Erişim 09 Ağustos 2020.

http://www.snto.ru/chto/upload/pdf/GNTP_05.pdf Erişim 09 Ağustos 2020.

https://bsv.ivran.ru/center Erişim 18 Ağustos 2020.

https://bsv.ivran.ru/sektor-turcii Erişim 16 Temmuz 2020.

https://islamansiklopedisi.org.tr/smirnov-vasily-dmitrievic Erişim 15 Ağustos 2020.

https://istatistik.yok.gov.tr/ Tablo 201. Yabancı uyruklu öğretim elemanlarının uyruğuna ve akademik görevlerine göre sayılar1, 2015 - 2016, 3. (20.05.2016).

https://vimeo.com/358652907/52c236e57b Erişim 01 Ağustos 2020.

https://ruxpert.ru/\%D0\%A0\%D0\%B0\%D0\%B7\%D0\%B2\%D0\%B0\%D0\%BB_\%D1\%81\%D0\%BE $\%$ D0 $\%$

B2\%D0\%B5\%D1\%82\%D1\%81\%D0\%BA\%D0\%BE\%D0\%B9_\%D0\%BD\%D0\%B0\%D1\%83\%D0

\%BA\%D0\%B8\#cite_note-.D0.9F.D0.B0.D0.B2.D0.BB.D0.BE.D0.B2-6 Erişim 07 A ğustos 2020.

https:/www.amerikaninsesi.com/a/a-17-2010-03-02-voa2-88926702/882376.html Erişim 07 Ağustos 2020. https://www.hurriyet.com.tr/dunya/siz-beni-sayiyor-musunuz-7727965 Erişim 20 Temmuz 2020 https://www.ivran.ru/persons/RobertLanda Erişim 09 Mart 2020.

https://www.milliyet.com.tr/gundem/yasakli-belgesel-kosk-un-sitesinde-982318 Erişim 01 Ağustos 2020. https://www.ncbi.nlm.nih.gov/pmc/articles/PMC1169423/ Erişim 09 Ağustos 2020

https://www.sciencemag.org/news/1996/10/russian-scientists-protest-money-woes Erişim 07 Ağustos 2020. https:/www.yenisafak.com/koronavirus/turkmenistanda-koronavirus-demek-artik-yasak-3532434 Erişim 28

Temmuz 2020.

https:/www.yenisafak.com/saglik/sahte-doktor-oldurdu-604845 Erişim 09 Ağustos 2020.

https:/youtu.be/XHekOu2Q18g Ковчег науки / Институту востоковедения Российской академии наук исполнилось 200 лет (Kovcheg nauki / Institutu vostokovedeniya Rossiyskoy akademii nauk ispolnilos' 200 let). Erişim 28 Temmuz 2020.

https://www.61 saat.com/sahte-universite-diplomalari-makale,2212.html Erişim 09 Ağustos 2020 